\title{
Fish helminths in Lithuanian inner waters
}

Vytautas Mažeika ${ }^{1^{*}}$,

Saulius Petkevičius ${ }^{2}$,

Egidijus Pumputis ${ }^{3}$,

Ričardas Krikštolaitis ${ }^{1}$

${ }^{1}$ Vytautas Magnus University,

K. Donelaičio St. 58,

Kaunas 44248, Lithuania

${ }^{2}$ Veterinary Academy

of the Lithuanian University

of Health Sciences,

Tilžès St. 18, Kaunas

47181, Lithuania

${ }^{3}$ State Food and Veterinary Service, Siesiku St. 19, Vilnius 07170, Lithuania
During the present investigation, 23 species of fish in Lithuanian inner waters were examined for helminth parasites. Of these, 63 taxa of helminths - 56 taxa of Plathyhelminthes, five of Nematoda, and two of Acanthocephales - were found. Monogenea Gyrodactylus truttae was registered in Lithuania for the first time. Metacercariae of flukes Diplostomum sp., Posthodiplostomum cuticula, and Tylodelphys clavata were found in the highest number of host species: 16,11, and 12, respectively. A generalized linear mixed model (GLMM) shows that six cyprinid species - Rutilus rutilus, Scardinius erythrophthalmus, Leuciscus leuciscus, Squalius cephalus, Blicca bjoerkna, and Abramis brama - have greater probability of infection with Diplostomum sp. metacercariae. The GLMM also shows that the random effect (the type of Lithuanian inner water body) was statistically significant. Differences in the prevalence of infection with Diplostomum sp., P. cuticula, and $T$. clavata metacercariae in different water body types were established for some fish species.

Keywords: helminths, fish, inner waters, Lithuania

\section{INTRODUCTION}

There are far more kinds of parasitic than nonparasitic organisms in the world and parasites may be one of the factors that regulate host populations (Roberts, Janovy, 2008). Parasitic diseases decrease fish growth rate and fertility, influence development of anomaly, decrease the quality of fish meat, and can cause mass death of fish. Manifestation of parasites can be different. Infected by digestive tract parasites, fish cannot assimilate a great part of nutrients and become exhausted. Parasites of the digestive tract, gill, and skin cause mechanical injuries with their attachment organs sometimes

\footnotetext{
*Corresponding author. Email: vytautas.mazeika@vdu.lt
}

leading to necrosis. Sites of injuries are a favourable medium for bacteria and fungi, which cause infectious diseases. Gill lamella hypertrophy, tumour formation, tissue injuries, and emergence of haemorrhages caused by monogenean infestation lead to a decrease of the respiratory surface and fish death because of hypoxia or anaemia. In aquaculture, diseases are among the most serious threats to commercial success (Noga, 2010). All these facts make the study of fish helminths relevant.

In Lithuania, investigation into fish helminths started at the beginning of the twentieth century. In 1909, Wegener studied helminths and other parasites in the Curonian Lagoon. Later, Szidat (1926, 1944) studied fish parasites in the Curonian Lagoon. In the Soviet period, a number of researchers studied fish parasites in natural water 
bodies and aquacultures: Sabina Gecevičiūtè, Rostislavas Krotas, S. A. Paškevičiūte, Edvardas Rauckis, Vytautas Keméža, A. D. Žaliūnienè, V. V. Marazas, V. A. Dogel, G. K. Petrushevskij, E. A. Bogdanova, B. E. Kazakov, E. N. Protasova, V. A. Rojtman, D. G. Tsejtlin, D. Kh. Khussein, A. A. Shigin and others. The bibliography of these works can be found in Rauckis's (1988) book in which the author provided an overview of fish parasites in Lithuania. Vytautas Oškinis (1993) studied fish helminths in the Lake Drūkšiai. The following researchers studied fish parasites in the Curonian Lagoon and the coastal region of the Baltic Sea: Stankus (1996), Bacevičius (2002, 2003, 2004, 2009), Bacevičius and Karalius (2008), Rakauskas et al. (2008), and Bagdonas et al. (2011). Bacevičius (2003) provided an overview of the studies on fish parasites in the Curonian Lagoon and the costal region of the Baltic Sea. Pilecka-Rapacz and Kesminas (2006) investigated the occurrence and intensity of the nematode Anguillicola crassus infection in eels in Lake Dringis. Rakauskas and Blaževičius $(2009,2010)$ studied parasites of the roach (Rutilus rutilus).

However, the composition of helminths may have undergone changes over time. The aim of the present study is to investigate helminths of freshwater fish in Lithuanian inner waters.

\section{MATERIALS AND METHODS}

Fish were sampled from June to November 2005 using electro-fishing and fyke nets at 55 study sites in 20 lakes, the Kaunas Hydroelectric Power Plant reservoir, the Curonian Lagoon and 13 different rivers (Figure). In total, 947 individuals of 23 fish species were examined for helminths:ten brown trouts Salmo trutta morpha fario L., 1758, two European whitefish Coregonus lavaretus (L., 1758), two vendaces Coregonus albula (L., 1758), 193 Northern pikes Esox Lucius L., 1758, 217 roaches Rutilus rutilus (L., 1758), 41 chubs Squalius cephalus (L., 1758), 42 common daces Leuciscus leuciscus (L., 1758), 140 rudds Scardinius erythrophthalmus (L., 1758), five belicas Leucaspius delin-

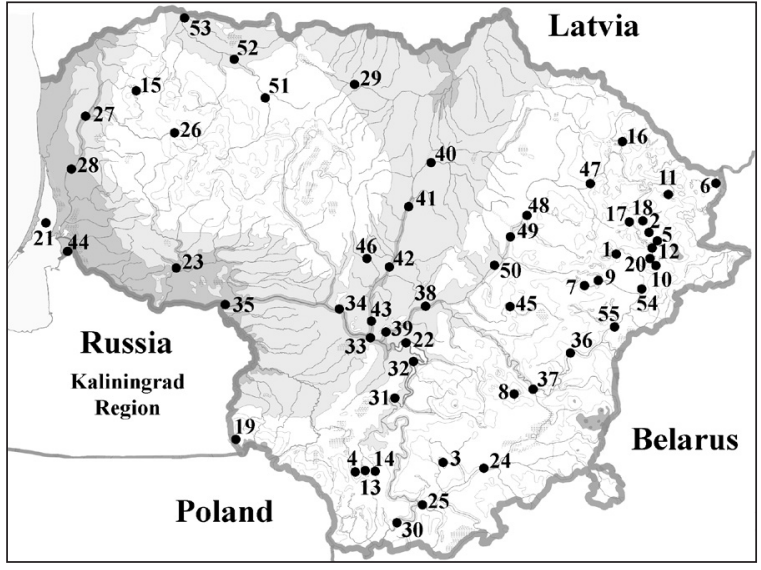

Figure. Study sites of fish helminths in Lithuania. Lakes: 1 - Aisetas, 2 - Baluošas, 3 - Didžiulis (Daugai), 4 - Dusia, 5 - Dringis, 6 - Drūkšiai, 7 - Galuonai, 8 - Galve, 9 - Kertuojai, 10 - Kretuonas, 11 - Luodis, 12 - Lūšiai, 13 - Metelys, 14 - Obelija, 15 - Plateliai, 16 - Sartai, 17 - Tauragnas, 18 - Utenas, 19 - Vištytis, 20 - Žeimenys; 21 - Curonian Lagoon; 22 - Kaunas hydropower plant reservoir; Rivers: 23 - Jūra under Tauragè, 24 - Merkys under Valkininkai, 25 - Merkys under Merkiné, 26 - Minija under Žarènai, 27 - Minija under Kartena, 28 - Minija under Gargždai, 29 - Mūša under Kulpe, 30 - Nemunas under Druskininkai, 31 - Nemunas under Prienai, 32 - Nemunas under Piliuona, 33 - Nemunas under Kaunas, 34 - Nemunas under Vilkija, 35 - Nemunas under Jurbarkas, 36 - Neris under Nemenčinè, 37 - Neris under Vilnius, 38 - Neris under Jonava, 39 - Neris at Kaunas confluence, 40 - Nevė̌̌is under Panevėžys, 41 - Nevèžis under Krekenava, 42 - Nevė̌iis under Kedainiai, 43 - Nevėžis under Babtai, 44 - Skirvytė under Rusnè, 45 - Širvinta under Širvintos, 46 - Šušvė under Josvainiai, 47 - Šventoji under Užpaliai, 48 - Šventoji under Anykščiai, 49 - Šventoji under Kovarskas, 50 - Šventoji under Ukmergè, 51 - Venta under Kuršènai, 52 - Venta under Venta, 53 - Venta under Mažeikiai, 54 - Žeimena under Švenčionèliai, 55 - Žeimena under Pabradè

eatus (Heckel, 1843), 28 tenches Tinca tinca (L., 1758), four gudgeons Gobio gobio (L., 1758), three bleaks Alburnus alburnus (L., 1758), 37 white breams Blicca bjoerkna (L., 1758), 16 freshwater breams Abramis brama (L., 1758), four vimba breams Vimba vimba (L., 1758), 
12 crucian carps Carassius carassius (L., 1758), ten Prussian carps Carassius gibelio (Bloch, 1782), five stone loaches Barbatula barbatula (L., 1758), four weatherfish Misgurnus fossilis (L., 1758), five burbots Lota lota (L., 1758), 29 ruffes Gymnocephalus cernua (L., 1758), 132 European perches Perca fluviatilis L., 1758, and six bullheads Cottus gobio L., 1758.

Lithuanian water bodies are divided into lakes, rivers, and the Curonian Lagoon; the Kaunas Hydroelectric Power Plant reservoir was considered as part of the Nemunas River. Fish distribution in different types of Lithuani- an water bodies in samples for helminthological studies is provided in Table 1.

Before necropsy, fish were killed by severing the spinal cord. Skin, fins, gills, mouth cavity, eyes, and viscera (intestine, mesentery, gall-bladder, gonads, liver, and kidney) were examined under a stereomicroscope following conventional methods described by Bykhovskaya-Pavlovskaya (1969).

Helminths were identified to the lowest possible taxa according to fish parasite keys (Bauer, 1985, 1987). Helminths were identified to the taxonomical level of species or at

Table 1. Fish distribution in different types of Lithuanian water bodies in sample for helminthological studies

\begin{tabular}{|c|c|c|c|c|c|c|c|c|}
\hline & \multirow[t]{2}{*}{ Fish species } & \multicolumn{2}{|c|}{ Lakes } & \multicolumn{2}{|c|}{ Rivers } & \multicolumn{2}{|c|}{ Curonian Lagoon } & \multirow{2}{*}{$\begin{array}{c}\text { Total } \\
\text { number }\end{array}$} \\
\hline & & Number & $\%$ & Number & $\%$ & Number & $\%$ & \\
\hline 1. & $\begin{array}{l}\text { Salmo trutta morpha } \\
\text { fario }\end{array}$ & 0 & 0.0 & 10 & 100.0 & 0 & 0.0 & 10 \\
\hline 2. & Coregonus lavaretus & 2 & 100.0 & 0 & 0.0 & 0 & 0.0 & 2 \\
\hline 3. & Coregonus albula & 2 & 100.0 & 0 & 0.0 & 0 & 0.0 & 2 \\
\hline 4. & Esox lucius & 15 & 7.8 & 178 & 92.2 & 0 & 0.0 & 193 \\
\hline 5. & Rutilus rutilus & 44 & 20.3 & 168 & 77.4 & 5 & 2.3 & 217 \\
\hline 6. & Squalius cephalus & 0 & 0.0 & 41 & 100.0 & 0 & 0.0 & 41 \\
\hline 7. & Leuciscus leuciscus & 0 & 0.0 & 42 & 100.0 & 0 & 0.0 & 42 \\
\hline 8. & $\begin{array}{c}\text { Scardinius erythroph- } \\
\text { thalmus }\end{array}$ & 85 & 60.7 & 55 & 39.3 & 0 & 0.0 & 140 \\
\hline 9. & Leucaspius delineatus & 0 & 0.0 & 5 & 100.0 & 0 & 0.0 & 5 \\
\hline 10. & Tinca tinca & 21 & 75.0 & 7 & 25.0 & 0 & 0.0 & 28 \\
\hline 11 & Gobio gobio & 0 & 0.0 & 4 & 100.0 & 0 & 0.0 & 4 \\
\hline 12. & Alburnus alburnus & 0 & 0.0 & 3 & 100.0 & 0 & 0.0 & 3 \\
\hline 13. & Blicca bjoerkna & 32 & 86.5 & 5 & 13.5 & 0 & 0.0 & 37 \\
\hline 14. & Abramis brama & 16 & 100.0 & 0 & 0.0 & 0 & 0.0 & 16 \\
\hline 15. & Vimba vimba & 0 & 0.0 & 4 & 100.0 & 0 & 0.0 & 4 \\
\hline 16. & Carassius carassius & 7 & 58.3 & 5 & 41.7 & 0 & 0.0 & 12 \\
\hline 17. & Carassius gibelio & 1 & 10.0 & 9 & 90.0 & 0 & 0.0 & 10 \\
\hline 18. & Barbatula barbatula & 0 & 0.0 & 5 & 100.0 & 0 & 0.0 & 5 \\
\hline 19. & Misgurnus fossilis & 0 & 0.0 & 4 & 100.0 & 0 & 0.0 & 4 \\
\hline 20. & Lota lota & 1 & 20.0 & 4 & 80.0 & 0 & 0.0 & 5 \\
\hline 21. & Gymnocephalus cernua & 21 & 72.4 & 8 & 27.6 & 0 & 0.0 & 29 \\
\hline 22. & Perca fluviatilis & 60 & 45.5 & 61 & 46.2 & 11 & 8.3 & 132 \\
\hline 23. & Cottus gobio & 0 & 0.0 & 6 & 100.0 & 0 & 0.0 & 6 \\
\hline & Total number & 307 & - & 624 & - & 16 & - & 947 \\
\hline
\end{tabular}


least genus. A small number of nematodes were not identified.

Helminthological terms were used according to the recommendations of Bush et al. (1997). The 95\% confidence intervals for prevalence were calculated as described by Rojtman and Lobanov (1985).

A generalized linear mixed model (GLMM) with negative binomial distribution and a log link was used to model particular helminth abundance data in 23 fish species. The GLMM was performed using IBM SPSS Statistics, version 20. Fish species was used as fixed effects and the type of Lithuanian inner water (lake, river or the Curonian Lagoon) was used as random effects. The primary statistical analysis using non-parametric $\chi^{2}$ criteria shows that it is possible to create a GLMM for just three helminths (Diplostomum sp. metacercariae, Posthodiplostomum cuticola (Nordmann, 1832) metacercariae, Tylodelphys clavata (Nordmann, 1832) metacercariae).

\section{RESULTS AND DISCUSSION}

In two examined C. lavaretus, two C. albula, four G. gobio, and five B. barbatula, no helminths were found. The examined fish of all other species were infected with helminths (Table 2). Sixty-three taxa of helminths were found. The largest number of helminth taxa was found in predatory fish E. lucius and P. fluviatilis, 20 and 18 , respectively. A relatively high number of helminth taxa was also found in abundant cyprinids $R$. rutilus and S. erythrophthalmus, 15 and 17, respectively. From two to 11 helminth taxa were found in fish of other species.

Helminths of three phyla were found: 56 taxa of Plathyhelminthes (17 Trematoda, 27 Monogenea, 12 Cestoda), five Nematoda, and two Acanthocephales. Monogenea was the most diverse taxon of the class rank.

Host numbers varied among the found helminths. Metacercariae of flukes Diplostomum sp., P. cuticola and T. clavata were found in the biggest number of host species; 16, 11, and 12, respectively. All other helminths were found in hosts of 1-7 species.
All helminths identified to species taxonomic level, except Gyrodactylus truttae Glaser, 1974, had already been found in Lithuania and mentioned by Rauckis (1988). Fluke Rhipidocotyle campanula (Dujardin, 1845) was mentioned by Rauckis (1988) under the name of Rhipidocotyle illense (Ziegler, 1883). Tapeworm Neogryporhynchus cheilancristrotus (Wedl, 1855) was mentioned by Rauckis (1988) under the name of Gryporhynchus cheilancristrotus (Wedl, 1855). Valipora campylocristrota (Wedl, 1855) was registered by Rauckis (1988) under the name of Valipora unilateralis (Rudolphi, 1819) Spasssky 1965.

Fluke Bucephalus polymorphus Baer, 1827 is a widespread fish parasite in Eurasia. The adult stage of this fluke parasitises predatory fish. The first intermediate host of the parasite is bivalve molluscs of the genera Unio, Anodonta and also Dreissena polymorpha (Pallas, 1771), metacercariae are found in different fish, mostly in cyprinids (Bykhovskaya-Pavlovskaya, Kulakova, 1987; Rauckis, 1988). In this study, B. polymorphus were found in E. lucius, R. rutilus, S. cephalus and P. fluviatilis.

Fluke R. campanula is a widespread fish parasite in Eurasia (Bykhovskaya-Pavlovskaya, Kulakova, 1987; Rauckis, 1988). The adult stages of the species parasitise predatory fish. The first intermediate host is bivalves (Rauckis, 1988), metacercariae are found in different fish, mostly in cyprinids (Bykhovskaya-Pavlovskaya, Kulakova, 1987). In this study, fluke R. campanula was found in E. lucius.

Phyllodistomum folium (Olfers, 1816) was found in fish of three species, E. lucius, R. rutilus, and P. fluviatilis. Intermediate hosts of the genus Phyllodistomum flukes are molluscs of the Anodonta and Dreissena genus and the Spheridae family (Rauckis, 1988). For the genus Phyllodistomum, encystment of cercariae inside sporocysts in an intermediate host is typical (Shultz, Gvozdev, 1972). P. folium is a characteristic parasite of E. lucius, yet it is found in other fish as well and its distribution coincides with the distribution of E. lucius in the Northern hemisphere (Bykhovskaya-Pavlovskaya, Kulakova, 1987). 


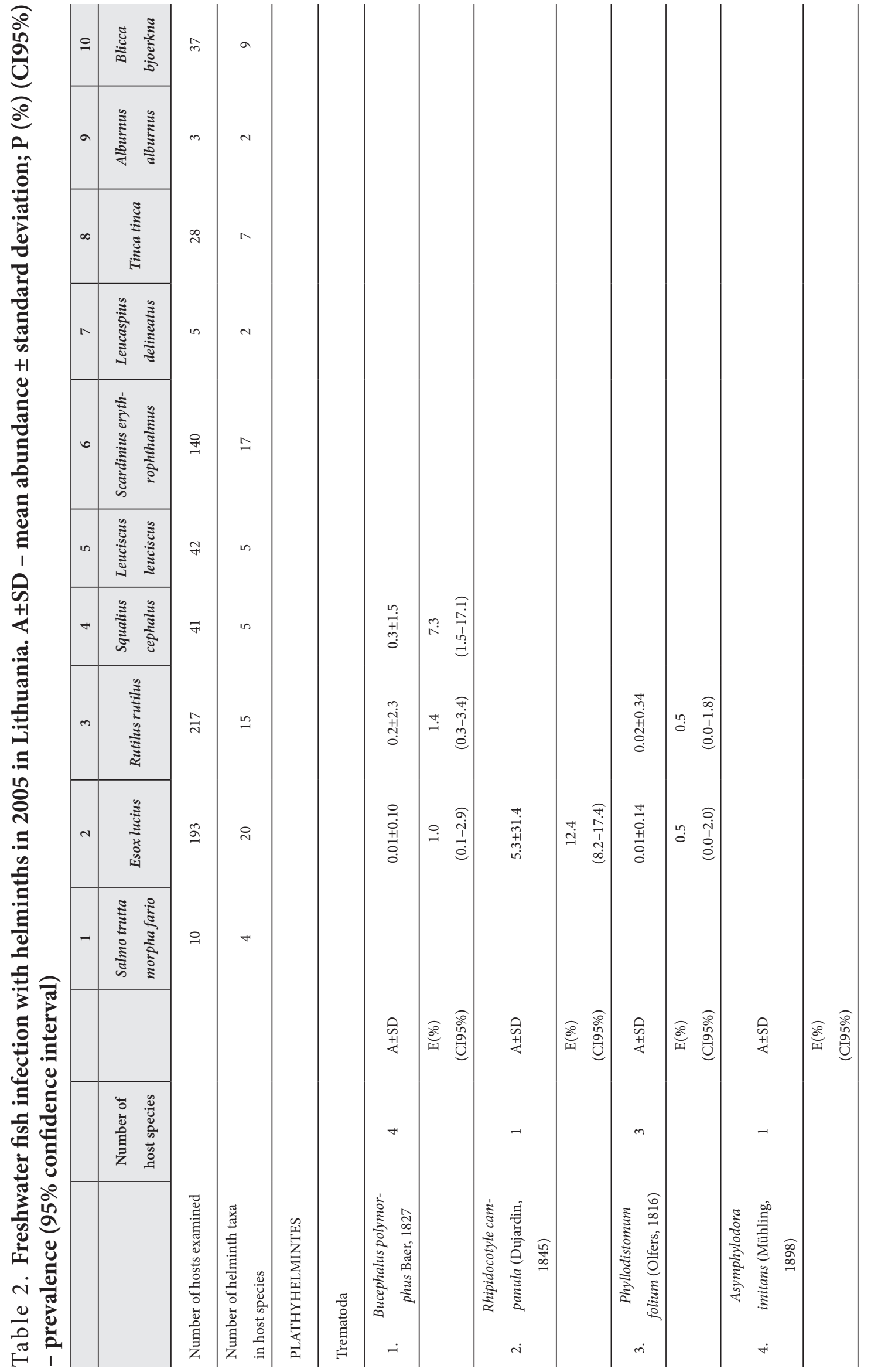




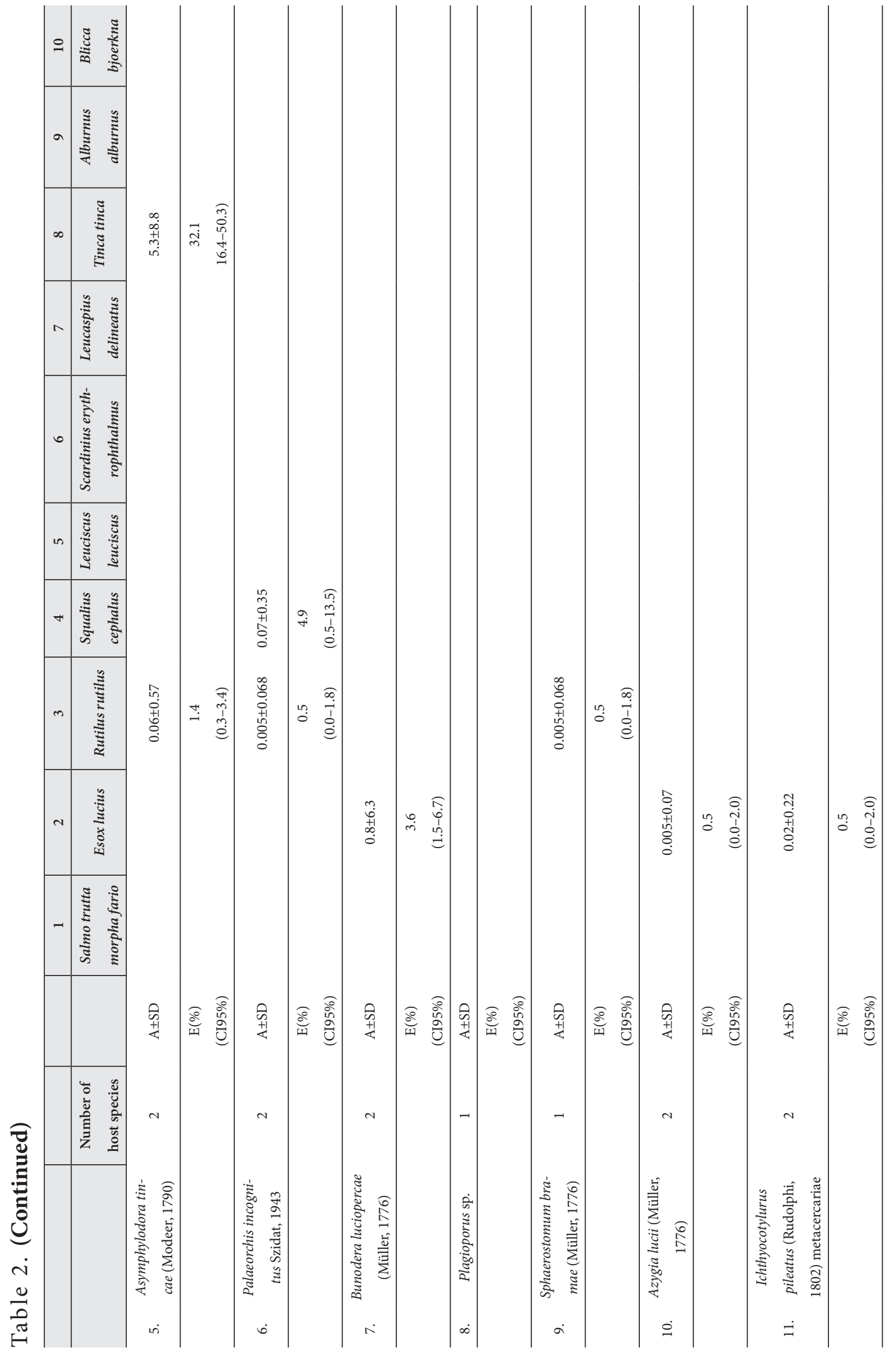




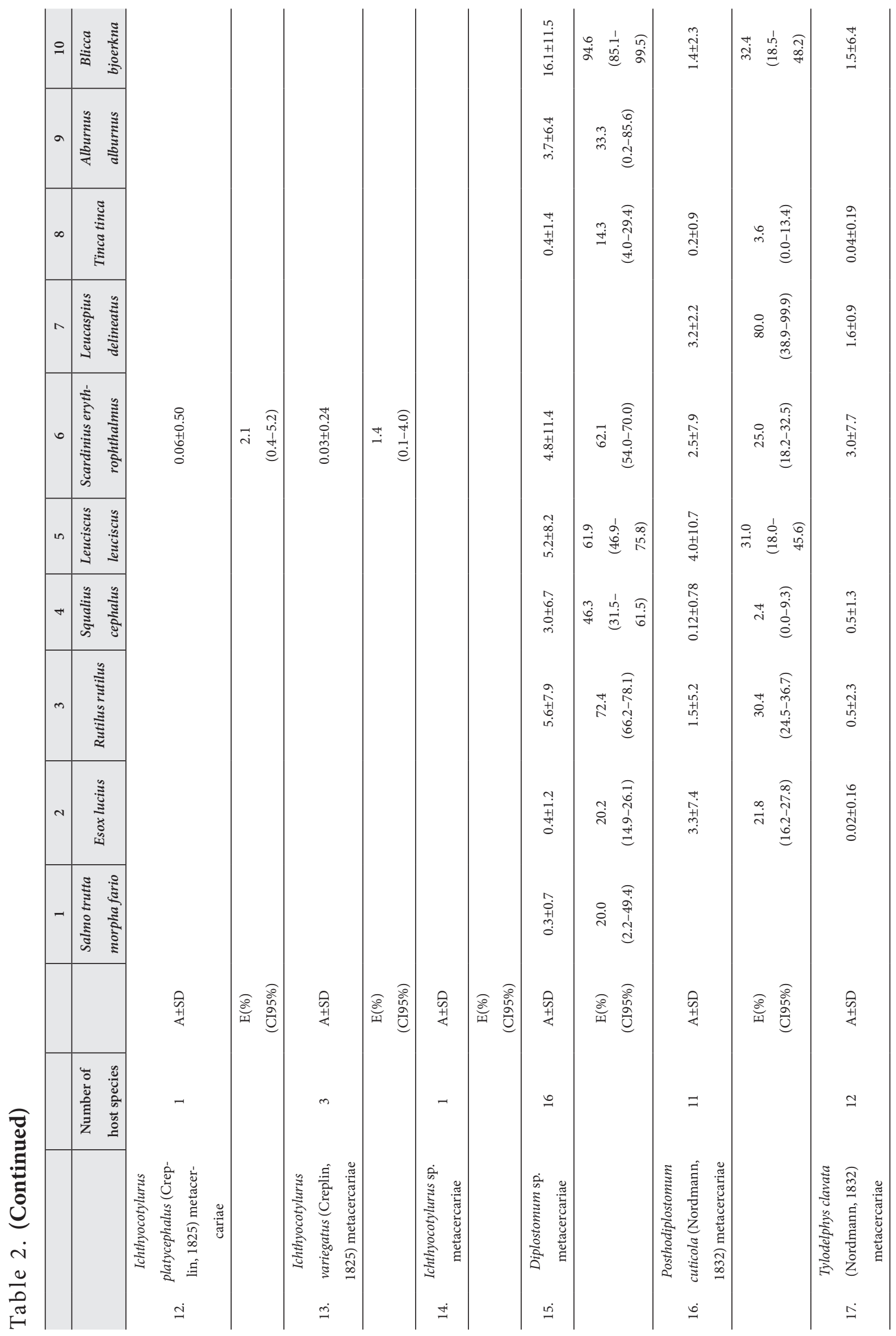




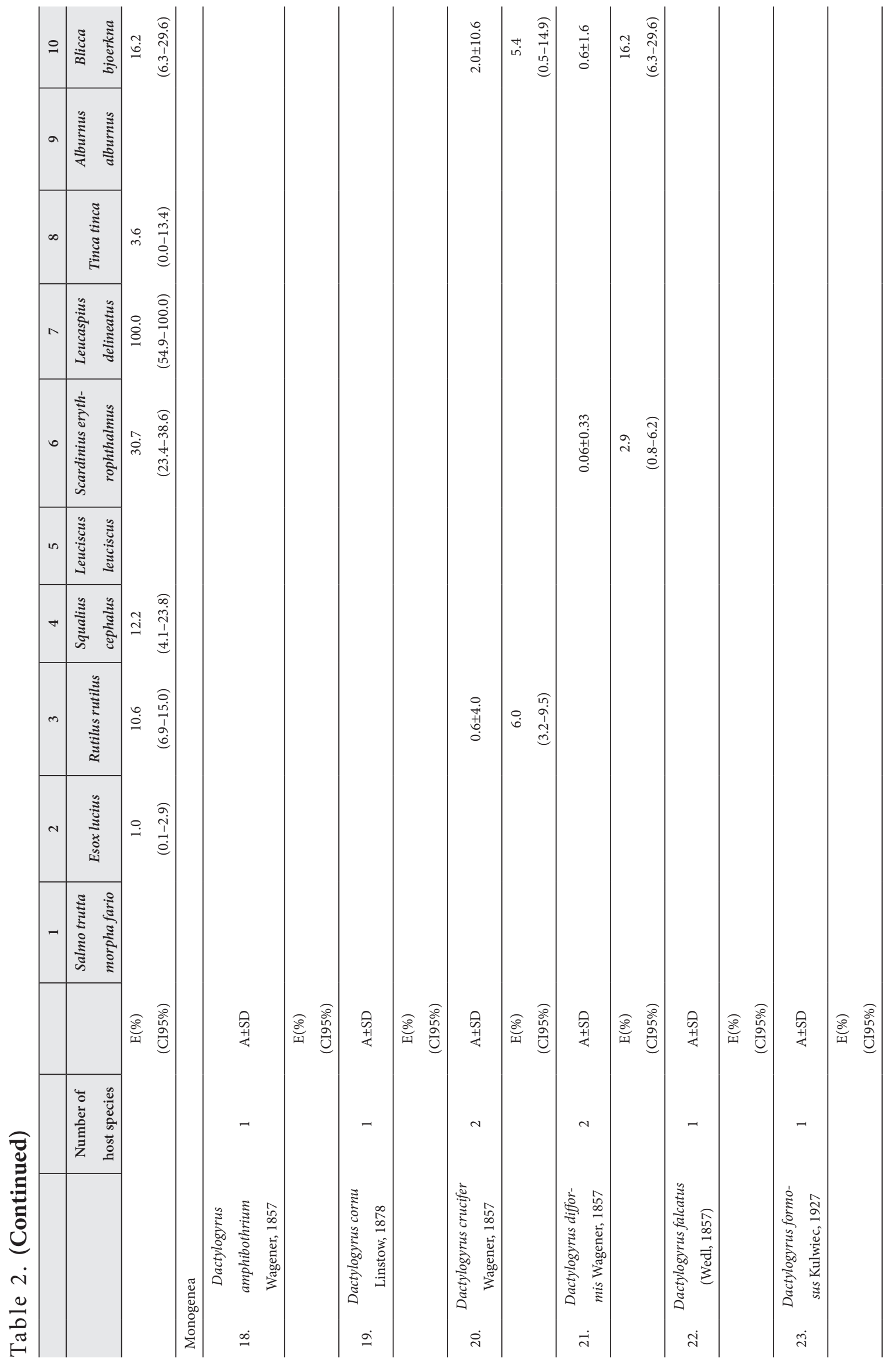




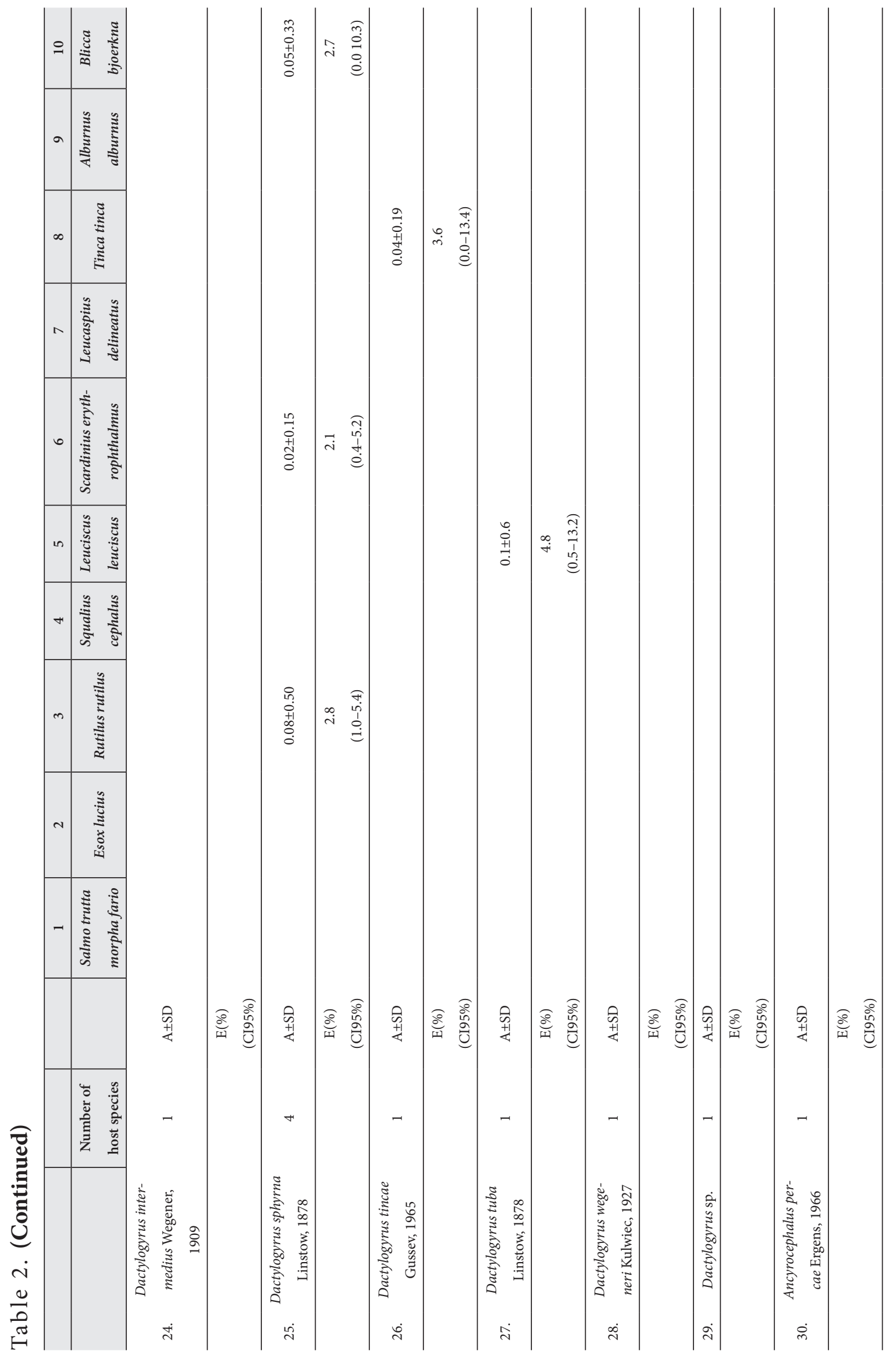




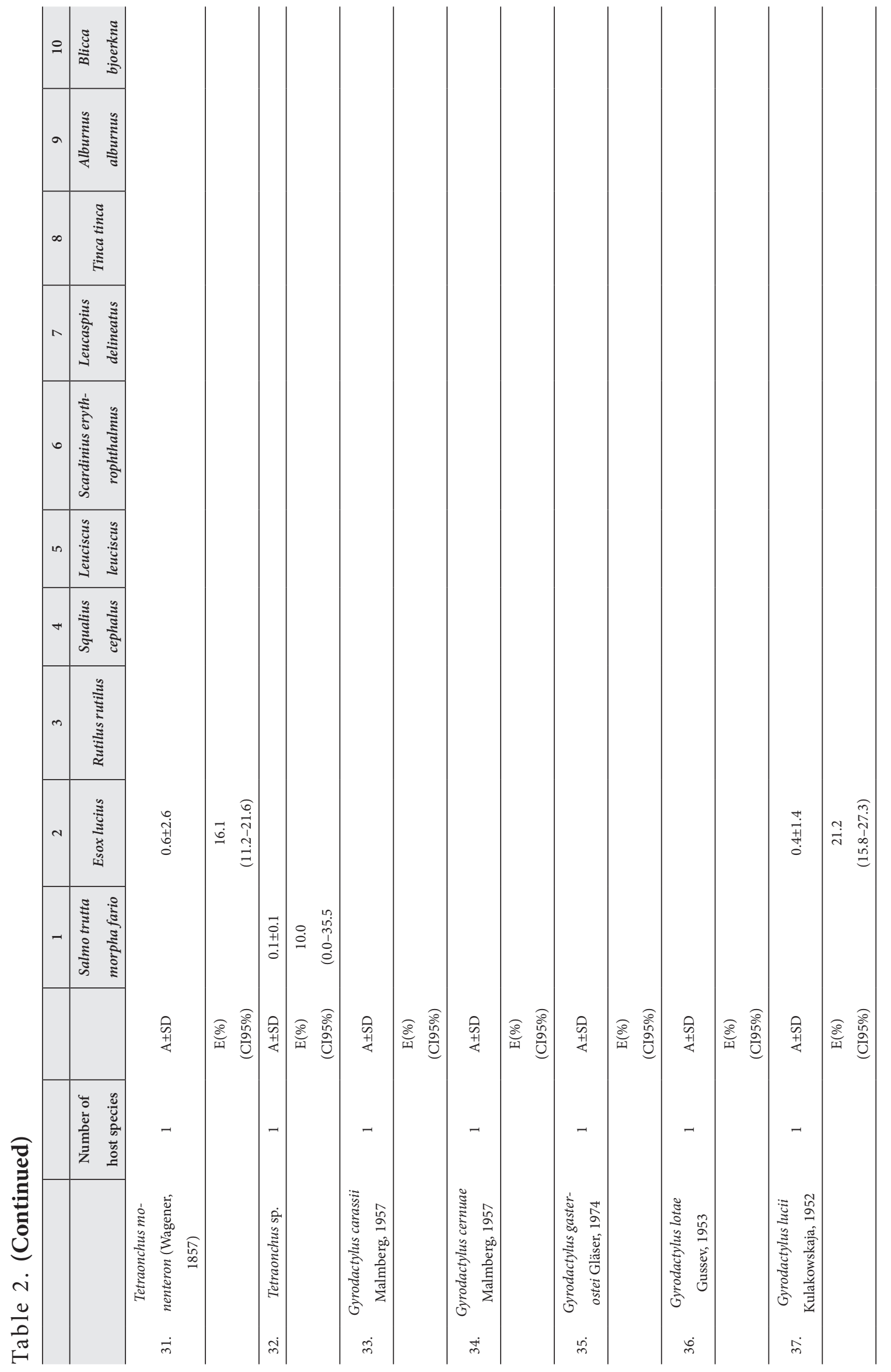




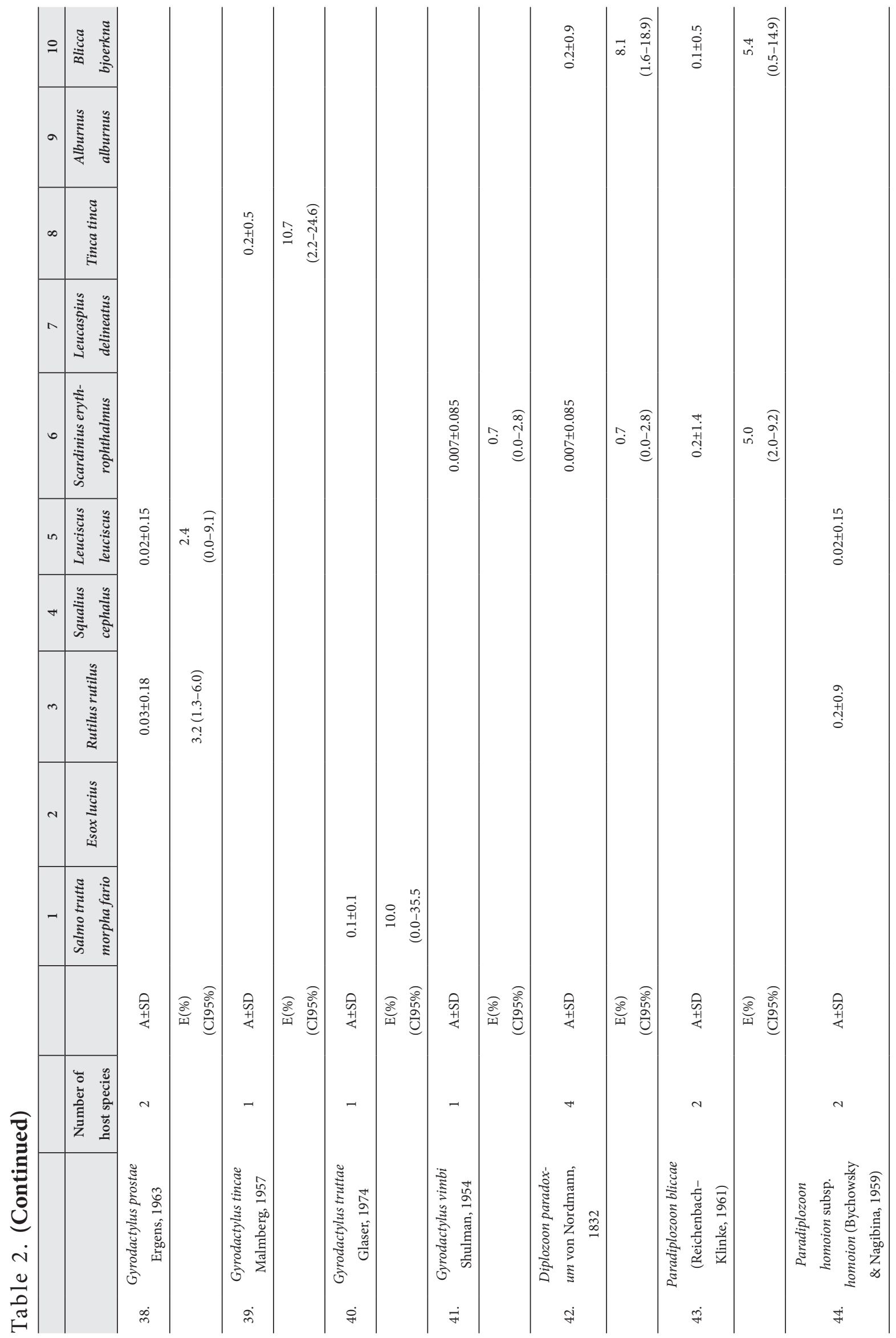




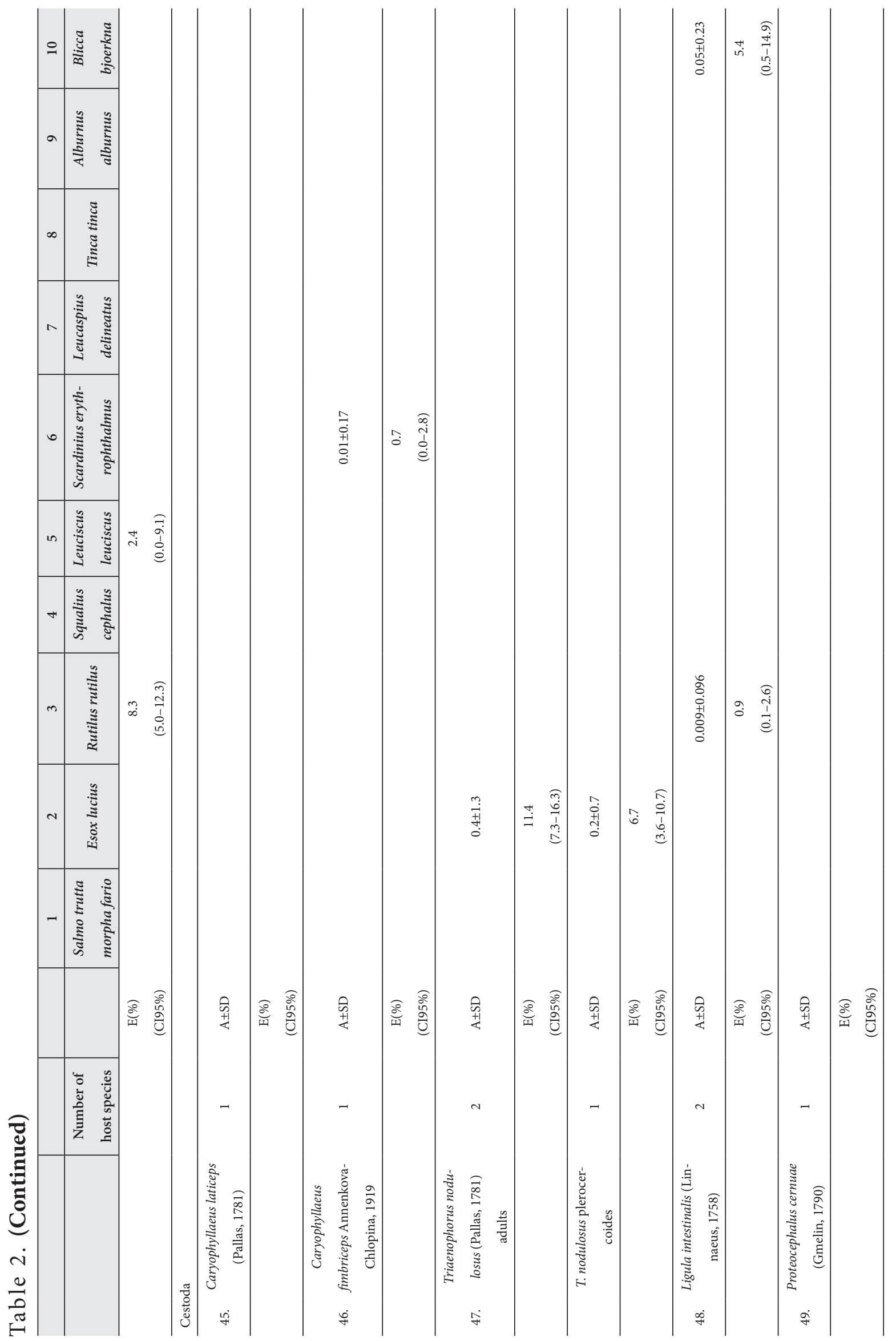




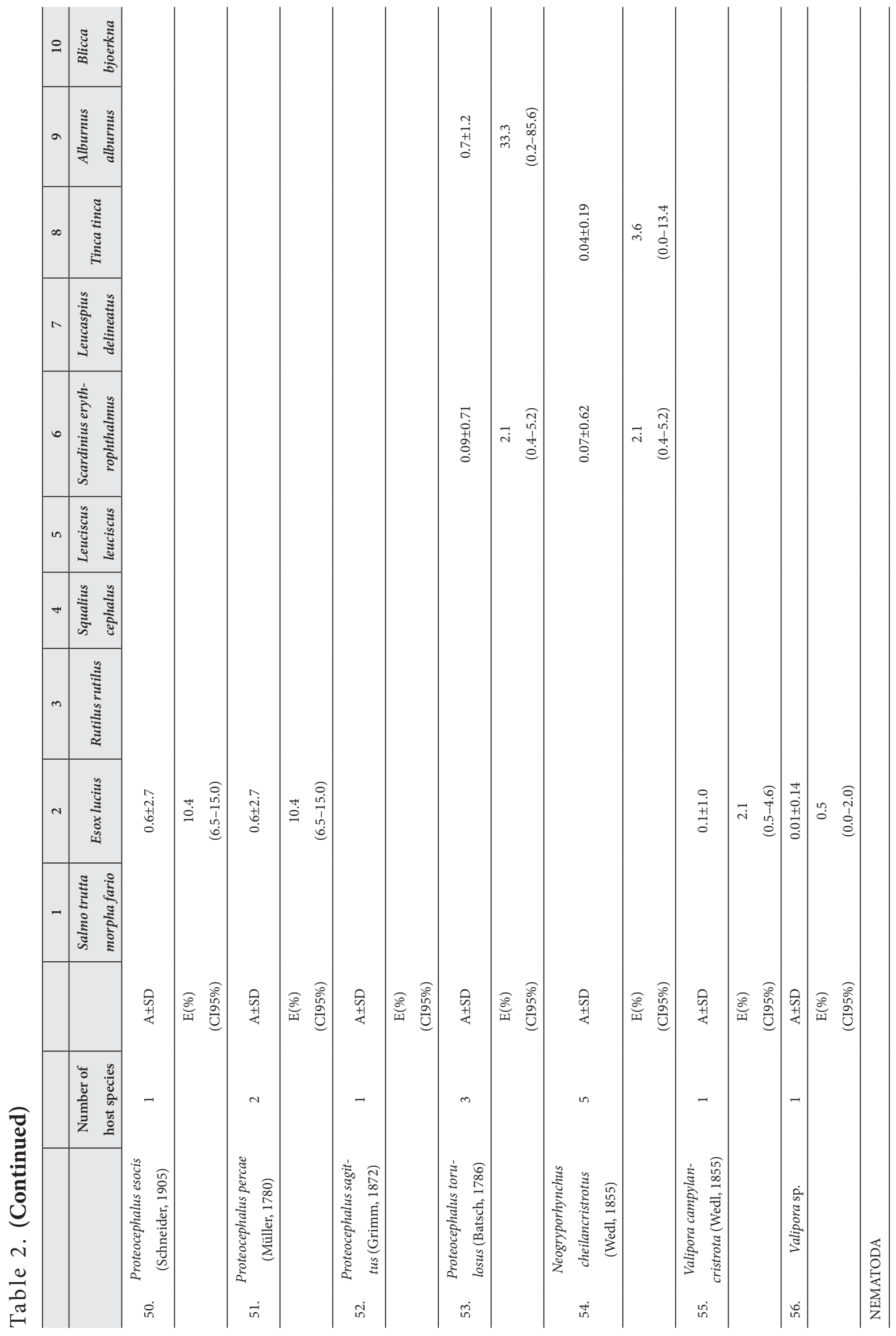




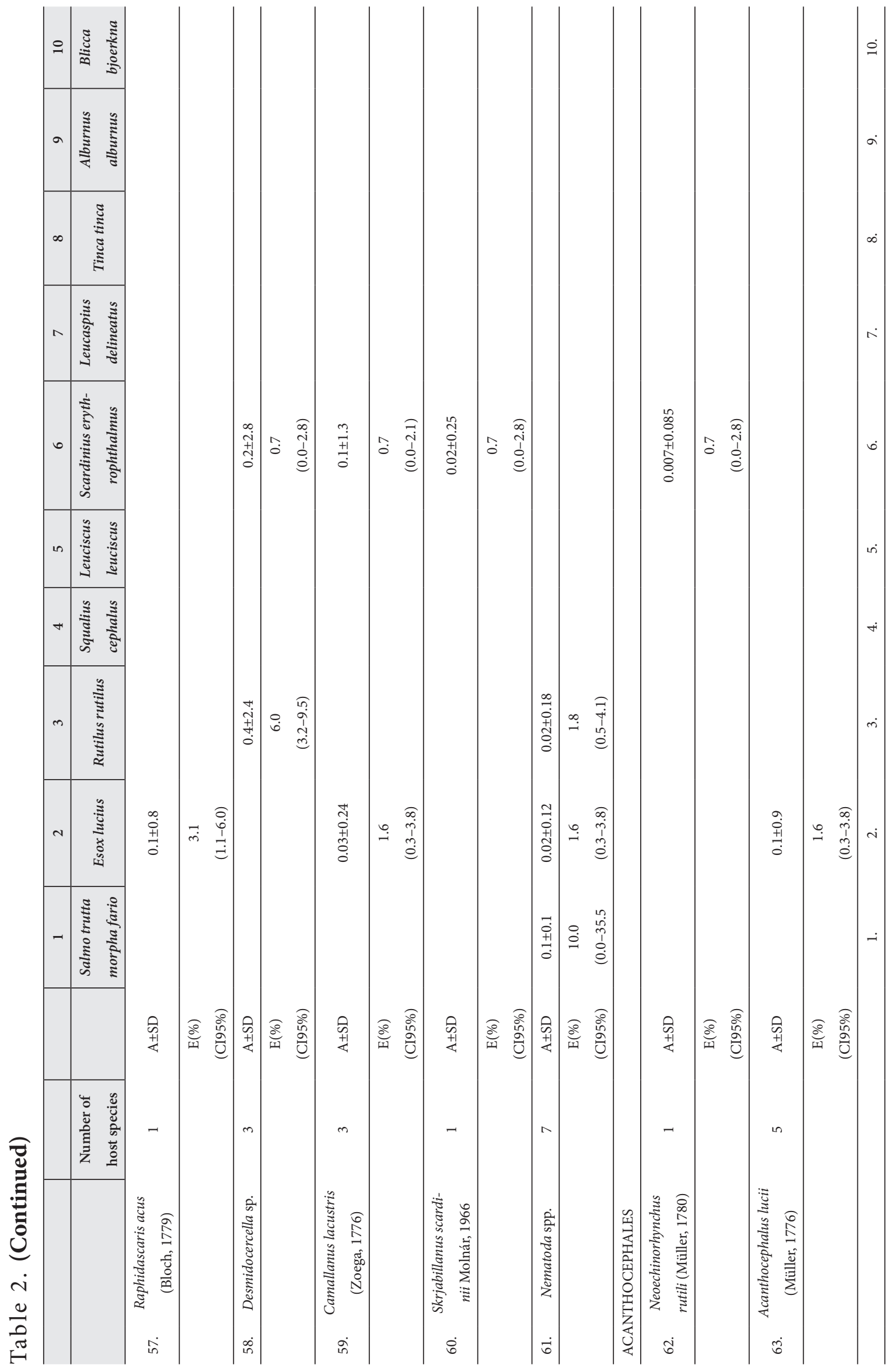




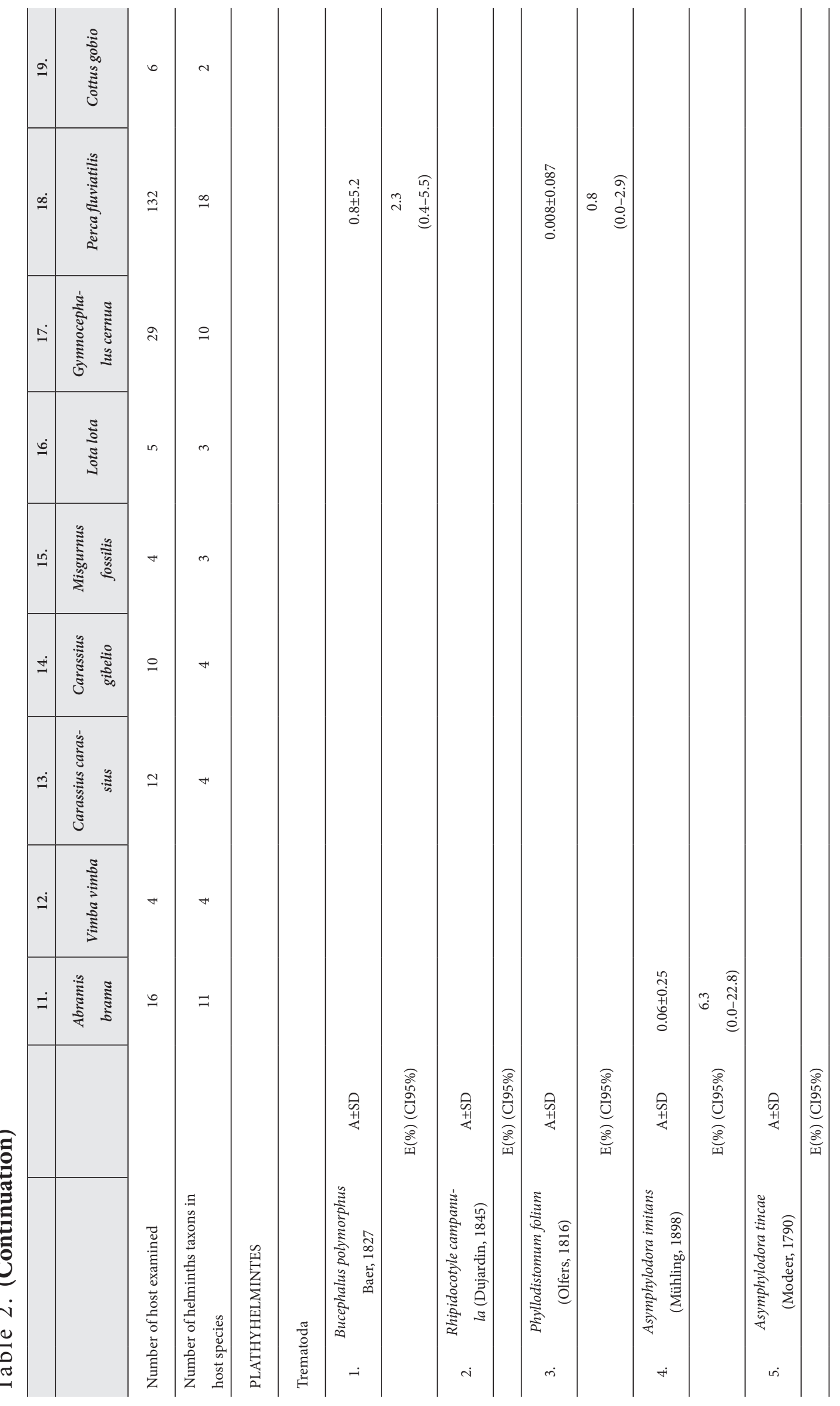




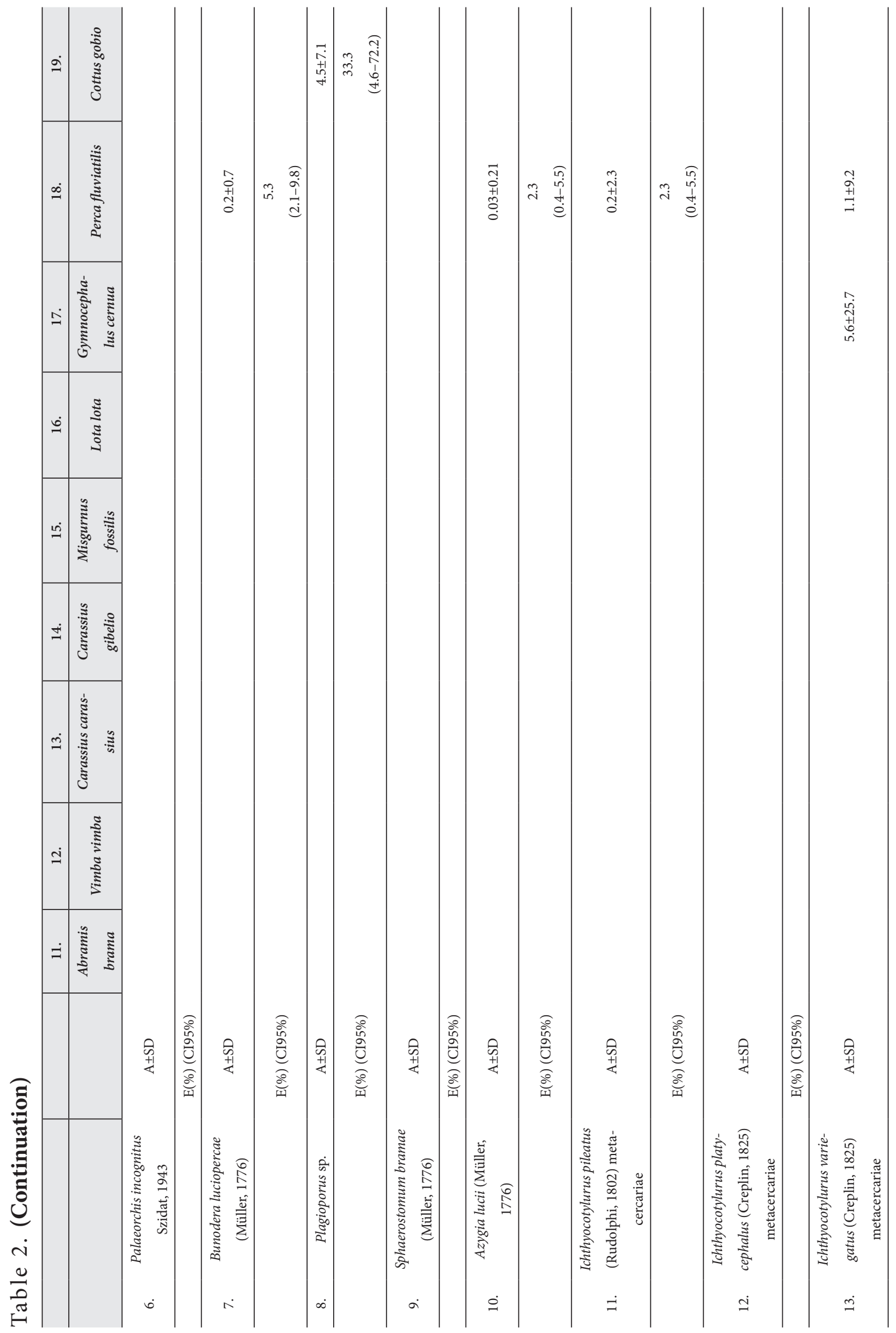




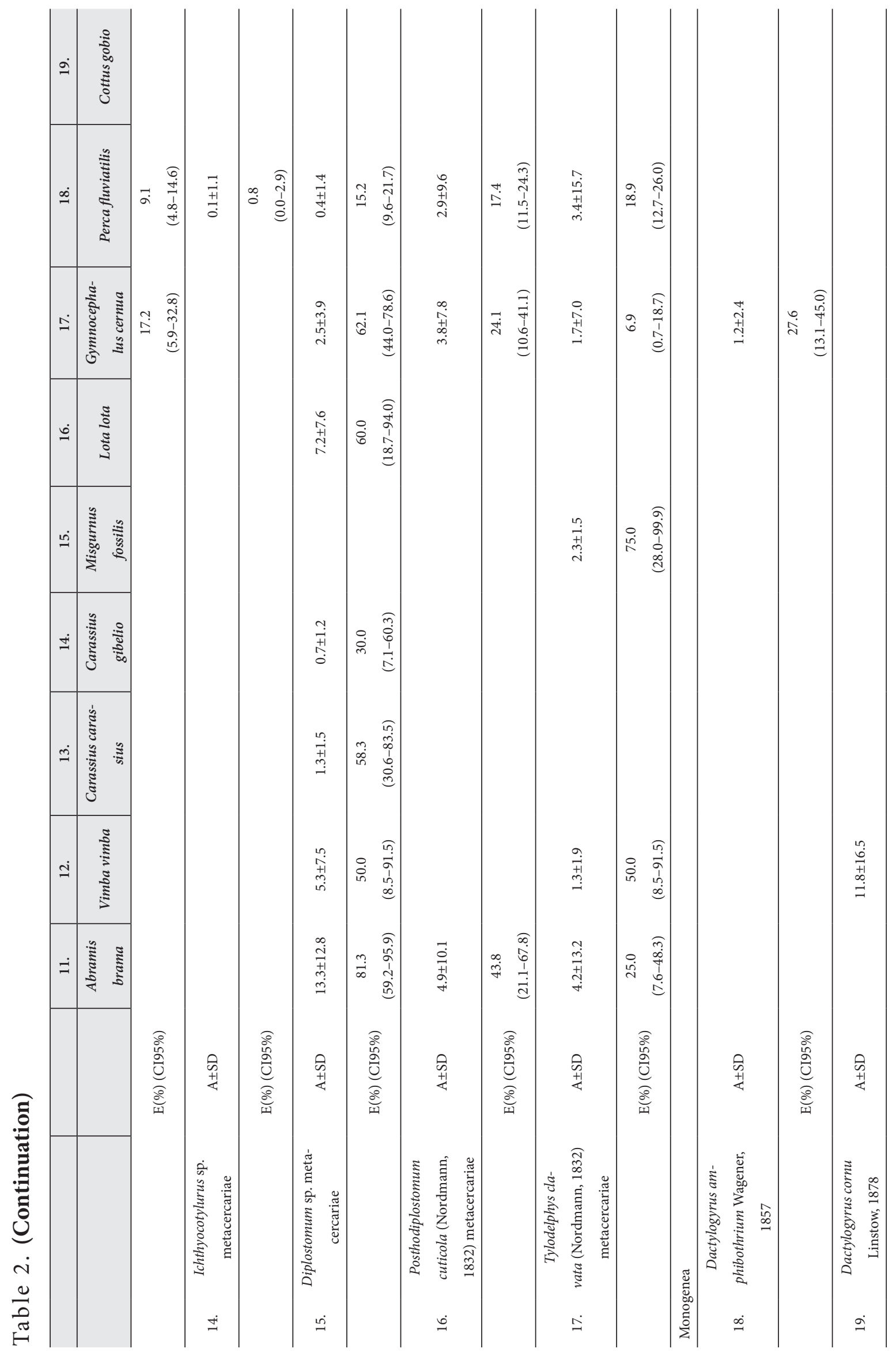




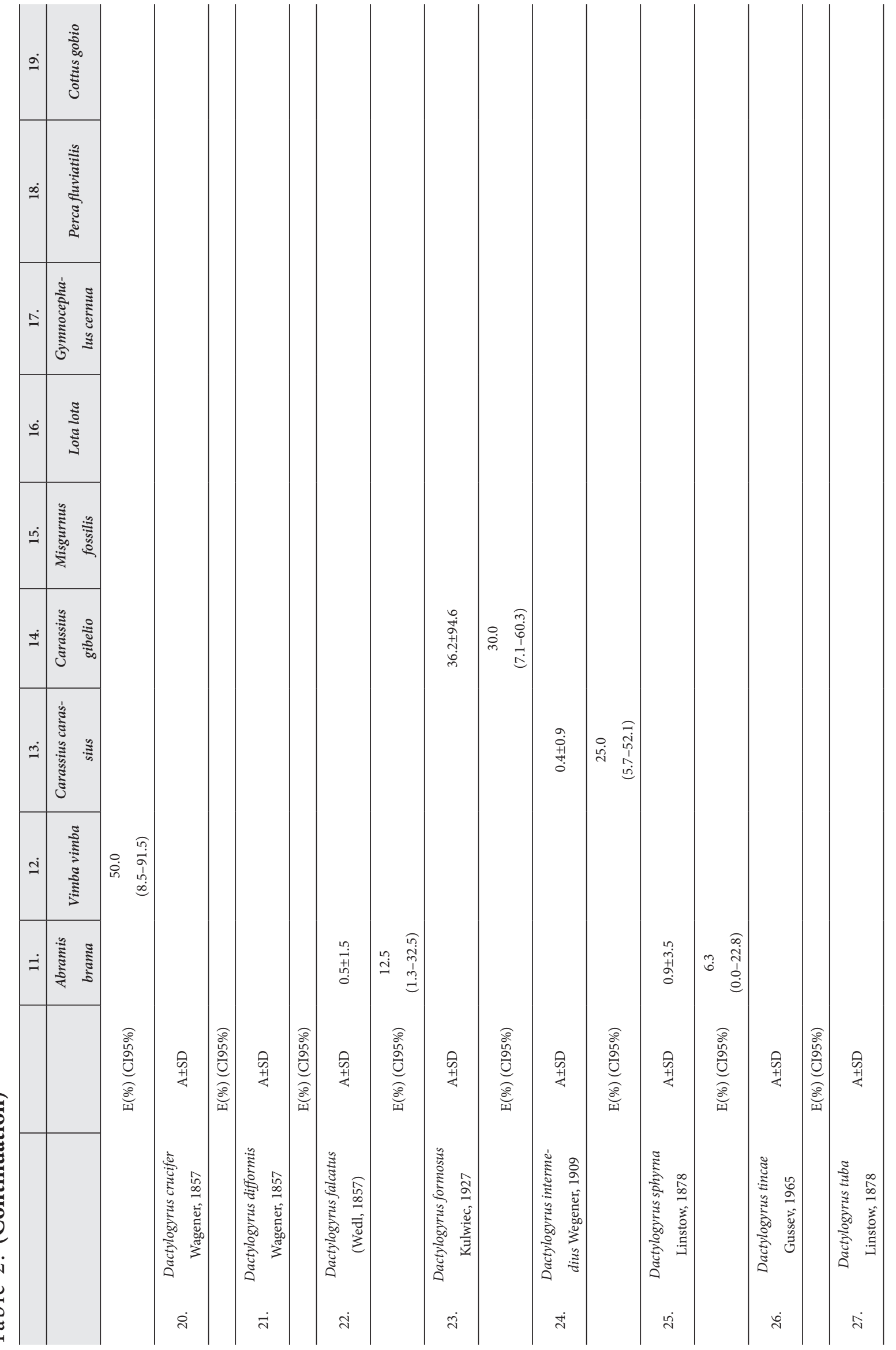




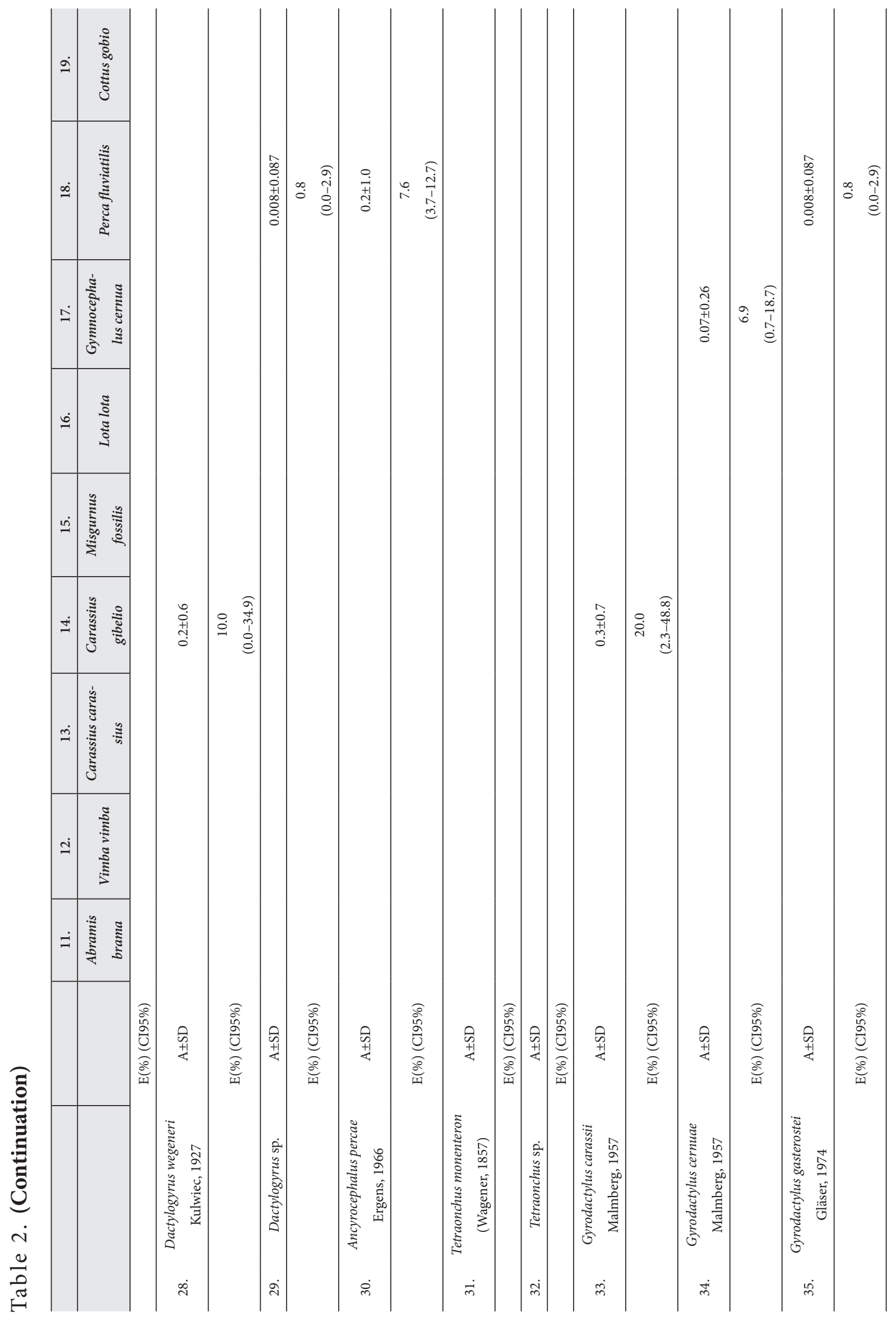




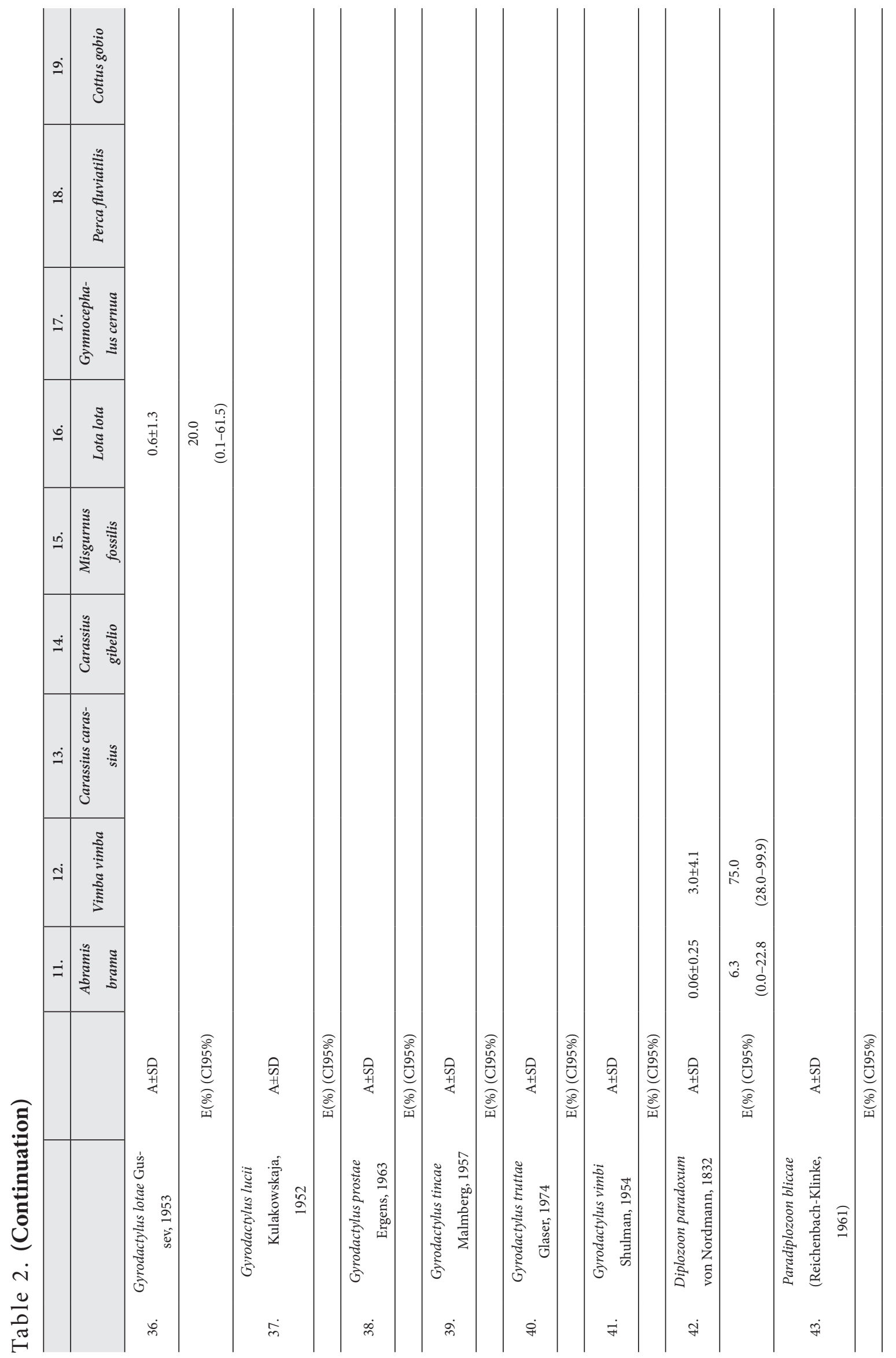




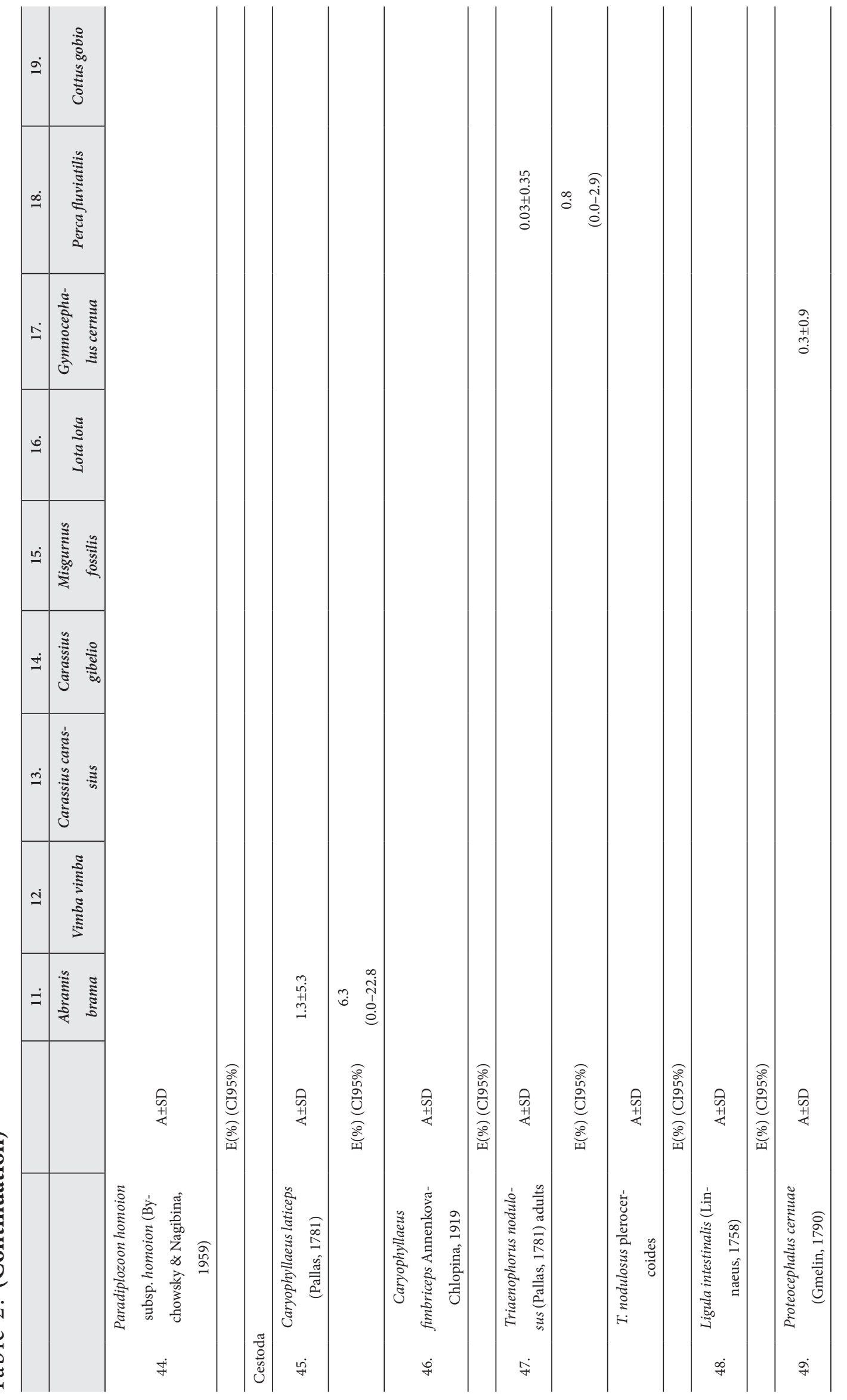




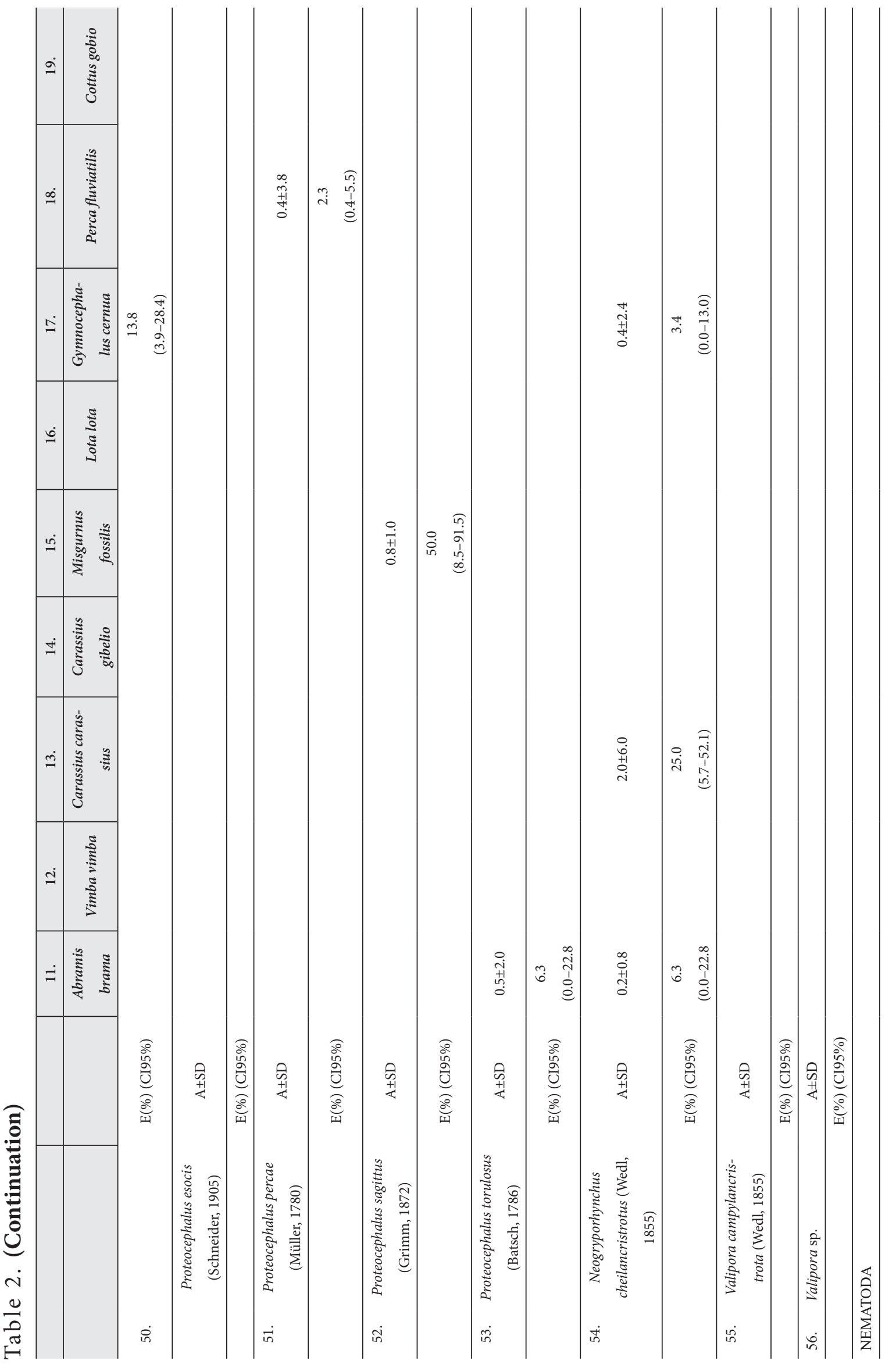




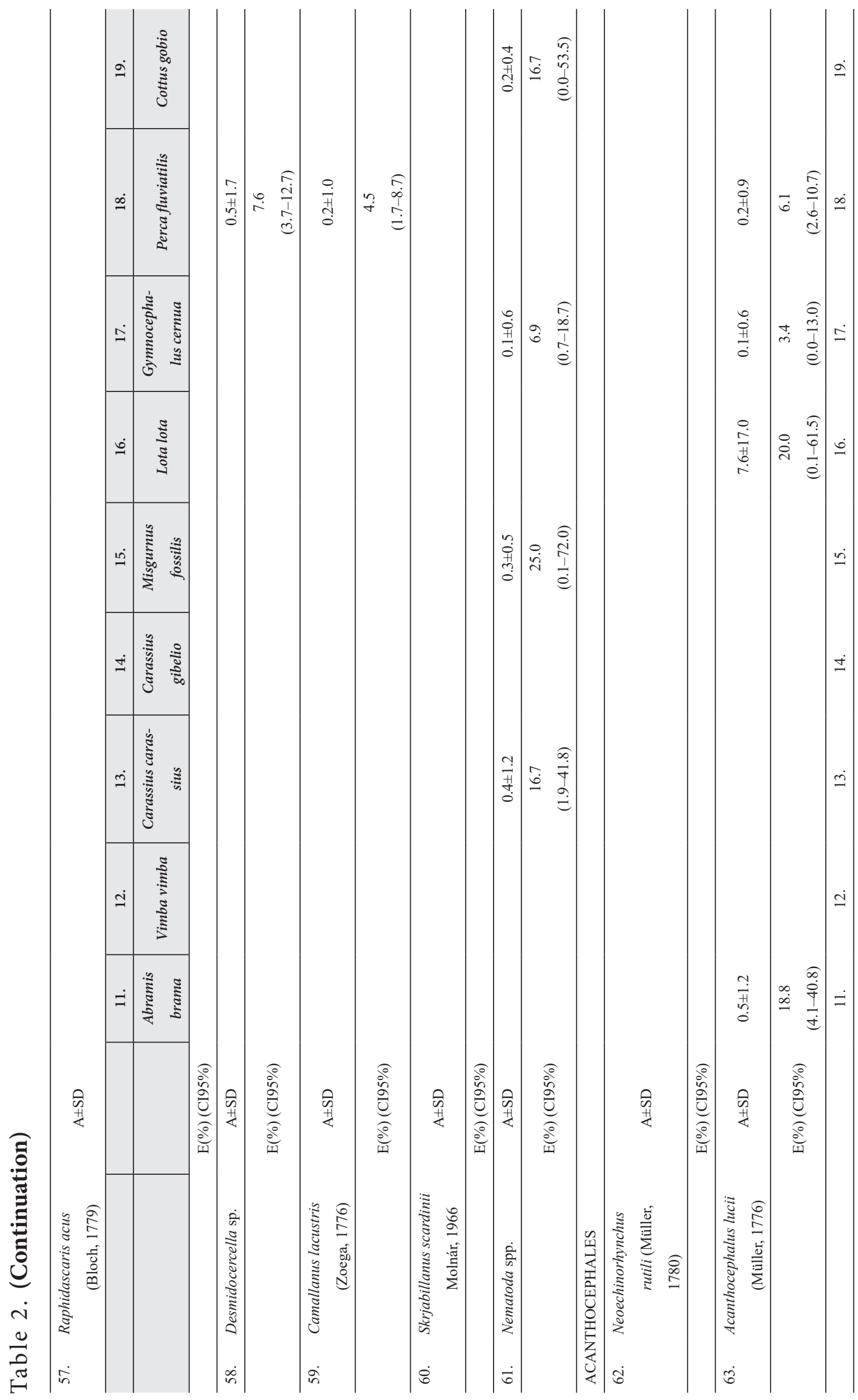


Two species of the genus Asymphylodora were found. Fluke Asymphylodora imitans (Mühling, 1898) was found in the intestines of A. brama. Asymphylodora tincae (Modeer, 1790) was found in the intestines of $R$. rutilus and T. tinca. Intermediate hosts of flukes of the genus Asymphylodora are molluscs of Bithynia, Radix and other genera (Rauckis, 1988). The metacercarial stage is absent in the life cycle of $A$. tincae and the definitive host becomes directly infected after the ingestion of snails harbouring rediae with mature cercariae (Našincová \& Scholz 1994). The distribution of $A$. tincae coincides with the distribution of T. tinca, yet this parasite is also found in others host species (Bykhovskaya-Pavlovskaya, Kulakova, 1987). A. imitans is found in basins of the Baltic, Black, Azov and Caspian seas (Bykhovskaya-Pavlovskaya, Kulakova, 1987).

Palaeorchis incognitus Szidat, 1943 was found in two species of fish, $R$. rutilus and S. cephalus. Intermediate hosts of flukes of the genus Palaeorchis are molluscs of Bithynia genus. These flukes parasitise mainly cyprinids. P. incognitus is distributed in the basins of the Baltic, Black, and Azov seas (Rauckis, 1988; BykhovskayaPavlovskaya, Kulakova, 1987). Snails Bithynia are the intermediate hosts of the genus Palaeorchis (Rauckis 1988).

Bunodera luciopercae (Müller, 1776) was found in E. lucius and P. fluviatilis. It is a widespread parasite in Eurasia and North America. Nuclear ribosomal DNA studies revealed possible existence of a cryptic species complex within the nominal species $B$. luciopercae (Petkevičiùte et al., 2010). The first intermediate hosts of this fluke are clams of the genera Sphaerium and Pisidium, the second intermediate hosts are Bosmina, Chydorus, Daphnia, Simocephalus, Eurycercus, Notodroma, and others (Bykhovskaya-Pavlovskaya, Kulakova, 1987; Ieshko, 1988; Rauckis, 1988). Planktivorous fish are infected by eating the second intermediate hosts. Predatory fish can be infected by eating planktivorous fish. Because of cannibalism, in P. fluviatilis population fluke B. luciopercae is transferred from one size-age group to another (Ieshko, 1988). In Lithuania, two subspecies of the fluke are found: B. luciopercae luciopercae (Müller, 1776) and B. luciopercae acerinae Rojtman et Sokolov, 1999 (Sokolov et al., 2006).

Plagioporus sp. was found in two of the six studied specimens of C. gobio. According to Rauckis (1988), two species of this genus are found in Lithuania: Plagioporus angusticolle (Hausmamm, 1899) and Plagioporus occidentalis Szidat, 1944. For some species of the Plagioporus genus, e.g. P. sinitsini Mueller, 1934, there are three potential pathways: a three-host life cycle involving molluscan, arthropod, and piscine hosts, a two-host life cycle involving only molluscan and piscine hosts, and a one-host life cycle involving only the snail host (Barger, Esch, 2000).

Fluke Sphaerostomum bramae (Müller, 1776) was found in $R$. rutilus. The definitive hosts of the flukes of the genus Sphaerostomum are cyprinids, but they are also found in fishes of other families (Zhokhov, 2002). The first intermediate host of $S$. bramae is mollusc Bithynia tentaculata and the second is leech Herpobdella (Bykhovskaya-Pavlovskaya, Kulakova, 1987). The range of S. bramae covers Europe (except for Scandinavia) and Western Siberia to the River Ob basin inclusive. Its northern boundary extends from the $\mathrm{Ob}$ Bay to lakes Onega and Ladoga. The southern boundary in Europe lies between the Greater and Lesser Caucasus. In Asia, it extends along the Emba and Irgiz rivers to Lake Zaisan and then ascends to the Verkhne-Chulymskie lakes in the Altai piedmonts (Zhokhov, 2002).

Fluke Azygia lucii (Müller, 1776) was found in predatory fish, E. lucius and P. fluviatilis. The main definitive host of this fluke is $E$. $l u$ cius, but it is also found in other fish. The range of the fluke coincides with the range of E. lucius (Bykhovskaya-Pavlovskaya, Kulakova, 1987). Intermediate hosts of fluke A. lucii are molluscs Anisus vortex, Radix ovata, Galba palustris, Planorbis planorbis, Gyraulus acronicus (Barskaya et al., 2008; Shultz, Gvozdev, 1972). Cercariae of this fluke are similar to larvae of Culicidae and are eaten by fry. In E. lucius, they develop into adult flukes; in fish that are not definitive hosts, they develop to metacercariae 
and reach maturity when these fish are eaten by E. lucius (Shultz, Gvozdev, 1972).

Metacercariae of three species of the genus Ichthyocotylurus were found. Ichthyocotylurus pileatus (Rudolphi, 1802) metacercariae were found in E. lucius, Ichthyocotylurus platycephalus (Creplin, 1825) metacercariae were found in S. erythrophthalmus, and Ichthyocotylurus variegatus (Creplin, 1825) metacercariae were found in fish of three species: S. erythrophthalmus, G. cernua and $P$. fluviatilis. Metacercariae of the genus Ichthyocotylurus not identified to the species level were found in P. fluviatilis. The first intermediate hosts of flukes of the genus Ichthyocotylurus are molluscs of Valvatidae (Rauckis, 1988). Metacercariae are found in fish. The definitive hosts of these flukes are piscivorous birds (Rauckis, 1988; Niewiadomska, 2001b).

Diplostomum sp. metacercariae were found in eye lens of 16 fish species: $S$. trutta morpha fario, E. lucius, R. rutilus, S. cephalus, L. leuciscus, S. erythrophthalmus, T. tinca, A. alburnus, B. bjoerkna, A. brama, V. vimba, C. carassius, C. gibelio, L. lota, G. cernua and P. fluviatilis. Systematics of the genus Diplostomum is still debated; species identification based only on morphology is complicated and molecular studies revealed a high level of species diversity (Niewiadomska, Laskowski, 2002; Galazzo et al., 2002; Locke et al., 2010a, b; Haarder et al., 2013). Because of this, we did not identify these metacercariae to the species level. Eyeflukes of the genus Diplostoma have three host life cycles. Definitive hosts are piscivorous birds. The first intermediate hosts are freshwater snails. In the case of Diplostomum spaethaceum, one of the species in which metacercariae are found in fish eye lens, the first intermediate hosts are limneids. Fish are the second intermediate hosts (Shultz, Gvozdev, 1972). Eyeflukes can be pathogenic to the fish host and cause poor growth, blindness, and, in certain situations, mass mortality in aquaculture of salmonids and cyprinids (Chappell et al., 1994).

The GLMM shows that six cyprinid species $-R$. rutilus, S. erythrophthalmus, L. leuciscus, S. cephalus, B. bjoerkna, and A. brama - have greater probability of infection with Diplostomum sp. metacercariae (or have a positive statistical significant impact $(p<0.05)$ on the parasite appearance) (Table 3 ). In these cyprinids, high infection prevalence and mean abundance values were identified; the highest values were registered in B. bjoerkna (Table 2). In order to determine the homogeneity of infection prevalence in the six selected fish species ( $R$. rutilus, S. erythrophthalmus, L. leuciscus, S. cephalus, B. bjoerk$n a$ and $A$. brama), a non-parametric $\chi^{2}$ test was performed. The obtained results $\left(\chi^{2}=37.106\right.$, $p=0.00)$ showed that there were statistically significant infection prevalence differences.

In addition, the GLMM shows that the random effect (the type of Lithuanian inner water) is also statistically significant at 0.05 level

Table 3. GLMM parameters for Diplostomum sp. metacercariae

\begin{tabular}{c|c|c|c|c|c|c}
\hline Model term & Coefficient & \multirow{2}{*}{ SE } & \multirow{2}{*}{$\boldsymbol{t}$} & \multirow{2}{*}{$\boldsymbol{p}$} & \multicolumn{2}{|c}{ 95\% confidence interval } \\
\cline { 5 - 7 } & & & & & Lower & Upper \\
\hline Intercept & -0.881 & 1.011 & -0.872 & 0.384 & -2.867 & 1.105 \\
\hline Rutilus rutilus & 2.327 & 0.842 & 2.763 & 0.006 & 0.672 & 3.981 \\
\hline Scardinius erythrophthalmus & 2.143 & 0.843 & 2.543 & 0.011 & 0.487 & 3.799 \\
\hline Leuciscus leuciscus & 2.474 & 0.848 & 2.917 & 0.004 & 0.808 & 4.140 \\
\hline Squalius cephalus & 1.818 & 0.825 & 2.205 & 0.028 & 0.198 & 3.439 \\
\hline Blicca bjoerkna & 3.435 & 0.884 & 3.884 & 0.000 & 1.697 & 5.172 \\
\hline Abramis brama & 3.397 & 0.951 & 3.573 & 0.000 & 1.529 & 5.264 \\
\hline Salmo trutta morpha fario & $0.000 \mathrm{a}$ & & & & & \\
\hline Negative Binomial & 2.110 &
\end{tabular}

\footnotetext{
a This coefficient is set to be zero because it is redundant.
} 
(Table 4). Different water body types differ in the structure of fish community, and infection parameters of some species are different in different water body types. Based on the data in Table 1, the homogeneity of the distribution of the six selected fish species (R. rutilus, S. erythrophthalmus, L. leuciscus, S. cephalus, B. bjoerkna and A. brama) in types of water bodies was evaluated using a non-parametric $\chi^{2}$ test. The obtained results $\left(\chi^{2}=189.173, p=0.000\right)$ showed that there was a statistically significant difference between fish distribution in Lithuanian inner water body types. This can be related with various habitat preferences of different fish species (Virbickas, 2000).

Differences of the prevalence of infection with Diplostomum sp. metacercariae in different types of water bodies were assessed using $\chi^{2}$ test. For some fish, species prevalence differences are significant, e.g., S. erythrophthalmus and B. bjoerkna (Table 5). Higher prevalence of infection in S. erythrophthalmus in rivers compared to lakes was ascertained. Prevalence in B. bjoerkna was higher in lakes.

$P$. cuticola metacercariae were found in skin and fins of 11 fish species: E. lucius, $R$. rutilus,

Table 4. GLMM random effect for Diplostomum sp. metacercariae

\begin{tabular}{c|c|c|c|c|c|c}
\hline Random Effect & \multirow{2}{*}{ Estimate } & SE & Z & \multirow{2}{*}{$p$} & \multicolumn{2}{|c}{ 95\% confidence interval } \\
\cline { 4 - 6 } & & & & & Lower & Upper \\
\hline Intercept & $0.321^{\mathrm{a}}$ & & & \\
\hline Type of inner water & 0.500 & 0.198 & 2.520 & 0.012 & 1.697 & 5.172 \\
\hline
\end{tabular}

a This parameter is redundant.

Table 5. Infection with Diplostomum sp. metacercariae in fish in different types of water bodies in Lithuania in 2005. N - number of fish studied; P(\%) - prevalence, $p$ - asymptotic significance level (2-sided)

\begin{tabular}{|c|c|c|c|c|c|c|c|c|c|c|}
\hline & \multirow[t]{2}{*}{ Fish species } & \multicolumn{2}{|c|}{ Lakes } & \multicolumn{2}{|c|}{ Rivers } & \multicolumn{2}{|c|}{ Curonian Lagoon } & \multicolumn{2}{|c|}{ Total } & \multirow[t]{2}{*}{$p$} \\
\hline & & $\mathrm{N}$ & $\mathrm{P}(\%)$ & $\mathrm{N}$ & $\mathrm{P}(\%)$ & $\mathbf{N}$ & $\mathrm{P}(\%)$ & $\mathbf{N}$ & $\mathrm{P}(\%)$ & \\
\hline 1. & Salmo trutta morpha fario & 0 & - & 10 & 20.0 & 0 & - & 10 & 20.0 & - \\
\hline 2. & Esox lucius & 15 & 20.0 & 178 & 20.2 & 0 & - & 193 & 20.2 & 0.983 \\
\hline 3. & Rutilus rutilus & 44 & 79.5 & 168 & 70.8 & 5 & 60.0 & 217 & 72.4 & 0.425 \\
\hline 4. & Squalius cephalus & 0 & - & 41 & 46.3 & 0 & - & 41 & 46.3 & - \\
\hline 5. & Leuciscus leuciscus & 0 & - & 42 & 61.9 & 0 & - & 42 & 61.9 & - \\
\hline 6. & $\begin{array}{l}\text { Scardinius erythrophthal- } \\
\text { mus }\end{array}$ & 85 & 55.3 & 55 & 72.7 & 0 & - & 140 & 62.1 & 0.038 \\
\hline 7. & Tinca tinca & 21 & 14.3 & 7 & 14.3 & 0 & - & 28 & 14.3 & 1.000 \\
\hline 8. & Alburnus alburnus & 0 & - & 3 & 33.3 & 0 & - & 3 & 33.3 & - \\
\hline 9. & Blicca bjoerkna & 32 & 100.0 & 5 & 60.0 & 0 & - & 37 & 94.6 & 0.000 \\
\hline 10. & Abramis brama & 16 & 81.3 & 0 & - & 0 & - & 16 & 81.3 & - \\
\hline 11. & Vimba vimba & 0 & - & 4 & 50.0 & 0 & - & 4 & 50.0 & - \\
\hline 12. & Carassius carassius & 7 & 57.1 & 5 & 60.0 & 0 & - & 12 & 58.3 & 0.921 \\
\hline 13. & Carassius gibelio & 1 & 100.0 & 9 & 22.2 & 0 & - & 10 & 30.0 & 0.107 \\
\hline 14. & Lota lota & 1 & 0.0 & 4 & 75.0 & 0 & - & 5 & 60.0 & 0.171 \\
\hline 15. & Gymnocephalus cernua & 21 & 71.4 & 8 & 37.5 & 0 & - & 29 & 62.0 & 0.092 \\
\hline 16. & Perca fluviatilis & 60 & 15.0 & 61 & 18.0 & 11 & 0.0 & 132 & 15.2 & 0.307 \\
\hline
\end{tabular}


S. cephalus, L. leuciscus, S. erythrophthalmus, L. delineatus, T. tinca, B. bjoerkna, A. brama, G. cernua, and P. fluviatilis. Flukes of the genus Posthodiplostomum have three-host life cycles (Shultz, Gvozdev, 1972). Definitive hosts are Ciconiiformes, metacercariae are found in cyprinids and other fish species, the genus is distributed universally (Niewiadomska 2001a; Bykhovskaya-Pavlovskaya, Kulakova, 1987).

The GLMM did not reveal any statistically significant dependencies for $P$. cuticola metacercariae.

Using $\chi^{2}$ test, significant differences of prevalence of infection with P. cuticola metacercariae in various water body types were established for E. lucius, G. cernua and P. fluviatilis (Table 6). In fish of these species P. cuticola metacercariae were found only in rivers.

T. clavata metacercariae were found in vitreous humour of 12 fish species: E. lucius, $R$. rutilus, S. cephalus, S. erythrophthalmus, L. delineatus, T. tinca, B. bjoerkna, A. brama, V. vimba, M. fossilis, G. cernua and P. fluviatilis. The definitive hosts of $T$. clavata are grebes, the first intermediate hosts are snails Radix ovata and others. Metacercariae are found in cyprinids and other fish (Shultz, Gvozdev, 1972; Bykhovskaya-Pavlovskaya, Kulakova, 1987).
The GLMM did not prove any statistically significant dependencies for $T$. clavata metacercariae.

Using $\chi^{2}$ test, significant differences in the prevalence of infection with T. clavata metacercariae in various water body types were established for R. rutilus, S. erythrophthalmus and P. fluviatilis (Table 7). In fish of these species, higher prevalence meanings were established in lakes or the Curonian Lagoon. Higher prevalence of infection in $R$. rutilus with T. clavata metacercariae in lakes compared to rivers has been already mentioned by Rakauskas and Blaževičius (2009) and explained by the lower numbers of Grebes in rivers compared with those in lakes.

Twenty-seven monogeneans were found, each on 1-4 host species. This is in agreement with the known fact that monogeneans are highly host specific, so that a given parasite species infects a single host species or a restricted number of host species (Šimková and Morand, 2008). The life cycles of monogeneans are direct without involvement of intermediate hosts. They are viviparous (Gyrodactylus) or oviparous (all other genera) (Shultz, Gvozdev, 1972). All monogenean species, except G. truttae, have already been found in Lithuania and are mentioned by Rauckis (1988). Monogenea G. truttae was found on the skin of S. trutta

Table 6. Infection with Posthodiplostomum cuticola metacercariae in fish in different types of water bodies in Lithuania in 2005. $\mathrm{N}$ - number of fish studied; $\mathrm{P}(\%)$ - prevalence, $p$ - asymptotic significance level (2-sided)

\begin{tabular}{c|c|c|c|c|c|c|c|c|c|c}
\hline & Fish species & \multicolumn{2}{|c|}{ Lakes } & \multicolumn{2}{|c|}{ Rivers } & \multicolumn{2}{c|}{ Curonian Lagoon } & \multicolumn{2}{c}{ Total } & $p$ \\
\hline & & $\mathbf{N}$ & $\mathbf{P}(\%)$ & $\mathbf{N}$ & $\mathbf{P}(\%)$ & $\mathbf{N}$ & $\mathbf{P}(\%)$ & $\mathbf{N}$ & $\mathbf{P}(\%)$ & \\
\hline 1. & Esox lucius & 15 & 0.0 & 178 & 23.6 & 0 & - & 193 & 21.8 & 0.033 \\
\hline 2. & Rutilus rutilus & 44 & 38.6 & 168 & 27.4 & 5 & 60.0 & 217 & 30.4 & 0.122 \\
\hline 3. & Squalius cephalus & 0 & - & 41 & 2.4 & 0 & - & 41 & 2.4 & - \\
\hline 4. & Leuciscus leuciscus & 0 & - & 42 & 31.0 & 0 & - & 42 & 31.0 & - \\
\hline 5. & Scardinius erythrophthalmus & 85 & 24.7 & 55 & 25.5 & 0 & - & 140 & 25.0 & 0.920 \\
\hline 6. & Leucaspius delineatus & 0 & - & 5 & 80.0 & 0 & - & 5 & 80.0 & - \\
\hline 7. & Tinca tinca & 21 & 0.0 & 7 & 14.3 & 0 & - & 28 & 3.6 & 0.078 \\
\hline 8. & Blicca bjoerkna & 32 & 34.4 & 5 & 20.0 & 0 & - & 37 & 32.4 & 0.523 \\
\hline 9. & Abramis brama & 16 & 43.8 & 0 & - & 0 & - & 16 & 43.8 & - \\
\hline 10. & Gymnocephalus cernua & 21 & 0.0 & 8 & 87.5 & 0 & - & 29 & 24.1 & 0.000 \\
\hline 11. & Perca fluviatilis & 60 & 0.0 & 61 & 37.7 & 11 & 0.0 & 132 & 17.4 & 0.000 \\
\hline
\end{tabular}


Table 7. Infection with Tylodelphys clavata metacercariae in freshwater fish in different types of water bodies in Lithuania in 2005. $\mathrm{N}$ - number of fish studied; $\mathrm{P}(\%)$ - prevalence, $p$ - asymptotic significance level (2-sided)

\begin{tabular}{|c|c|c|c|c|c|c|c|c|c|c|}
\hline & \multirow[t]{2}{*}{ Fish species } & \multicolumn{2}{|c|}{ Lakes } & \multicolumn{2}{|c|}{ Rivers } & \multicolumn{2}{|c|}{ Curonian Lagoon } & \multicolumn{2}{|c|}{ Total } & \multirow[t]{2}{*}{$p$} \\
\hline & & $\mathbf{N}$ & $\mathrm{P}(\%)$ & $\mathbf{N}$ & $\mathrm{P}(\%)$ & $\mathbf{N}$ & $\mathrm{P}(\%)$ & $\mathrm{N}$ & $\mathrm{P}(\%)$ & \\
\hline 1. & Esox lucius & 15 & 0.0 & 178 & 1.1 & 0 & - & 193 & 1.0 & 0.680 \\
\hline 2. & Rutilus rutilus & 44 & 9.1 & 168 & 9.5 & 5 & 60.0 & 217 & 10.6 & 0.001 \\
\hline 3. & Squalius cephalus & 0 & - & 41 & 12.2 & 0 & - & 41 & 12.2 & - \\
\hline 4. & Scardinius erythrophthalmus & 85 & 40.0 & 55 & 16.4 & 0 & - & 140 & 30.7 & 0.003 \\
\hline 5. & Leucaspius delineatus & 0 & - & 5 & 100.0 & 0 & - & 5 & 100.0 & - \\
\hline 6. & Tinca tinca & 21 & 4.8 & 7 & 0.0 & 0 & - & 28 & 3.6 & 0.557 \\
\hline 7. & Blicca bjoerkna & 32 & 18.8 & 5 & 0.0 & 0 & - & 37 & 16.2 & 0.290 \\
\hline 8. & Abramis brama & 16 & 25.0 & 0 & - & 0 & - & 16 & 25.0 & - \\
\hline 9. & Vimba vimba & 0 & - & 4 & 50.0 & 0 & - & 4 & 50.0 & - \\
\hline 10. & Misgurnus fossilis & 0 & - & 4 & 75.0 & 0 & - & 4 & 75.0 & - \\
\hline 11. & Gymnocephalus cernua & 21 & 9.5 & 8 & 0.0 & 0 & - & 29 & 6.9 & 0.366 \\
\hline 12. & Perca fluviatilis & 60 & 36.7 & 61 & 3.3 & 11 & 9.1 & 132 & 18.9 & 0.000 \\
\hline
\end{tabular}

morpha fario. The species is a widespread parasite in S. trutta morpha fario and rainbow trout Oncorhynchus mykiss (Walbaum, 1792) (Ergens, 1985).

Two species of the genus Caryophyllaeus were found: tapeworm Caryophyllaeus laticeps (Pallas, 1781) was found in A. brama and tapeworm Caryophyllaeus fimbriceps Annenkova-Chlopina, 1919 was found in S. erythrophthalmus. Tapeworms of the Caryophyllaeus genus have two-host life cycles. The main definitive hosts of $C$. laticeps are A. brama, B. bjoerkna, white-eye bream Ballerus sapa (Pallas, 1814), V. vimba, and R. rutilus; it also parasitises S. cephalus, ide Leuciscus idus (L., 1758), S. erythrophthalmus, asp Leuciscus aspius (L., 1758), barbel Barbus barbus (L., 1758), and other cyprinids; intermediate hosts of the species are annelids Tubifex tubifex, T. barbatus, and Limnodrilus claperedeanus (Shultz, Gvozdev, 1972; Dubinina, 1987). The definitive hosts of tapeworm C. fimbriceps are wild and domesticated common carps Cyprinus carpio L., 1758, more rarely A. brama, but this parasite also parasitises T. tinca, $S$. cephalus, and R. rutilus. Intermediate hosts of tapeworm $C$. fimbriceps are annelids T. tubifex, T. barbatus, Psammoryctes albicola, and Limnodrilus udekemianus (Shultz, Gvozdev, 1972; Dubinina, 1987).

Adult tapeworms Triaenophorus nodulosus (Pallas, 1781) were found in the intestines of E. lucius and P. fluviatilis. Plerocercoides of the species were found in livers of E. lucius. This tapeworm has free living coracidium which is swallowed by crustaceans, the first intermediate hosts: Cyclops strenuus, Microcyclops varicans, Mesocyclops oithonoides, Macrocyclops fuscus, Acanthocyclops bicuspidatus, Eucyclops serrulatus, Eudiaptomus gracilus, and others. In the body cavity of crustaceans, procercoids are formed. When crustaceans are eaten by fish, the second intermediate host, plerocercoids, form in them. Definitive hosts are infected when they eat the second intermediate hosts. The definitive hosts of T. nodulosus are E. lucius and other predatory fish. The second intermediate hosts are the same predatory fish and also other fish species (Shultz, Gvozdev, 1972; Dubinina, 1987; Rauckis, 1988).

Plerocercoids of Ligula intestinalis (L., 1758) were found in R. rutilus and B. bjoerkna. The definitive hosts of $L$. intestinalis are gulls and other piscivorious birds. The tapeworm has a free-living stage, coracidium. Procercoids 
develop in crustaceans, the first intermediate hosts: Cyclops strenuus, Acanthocyclops bicuspidatus, A. viridis, Mesocyclops oithonoides, Eudiaptomus gracilus, and E. graciloides. Fish represent the second intermediate host. Plerocercoids are found in body cavities of R. rutilus, L. leuciscus, S. cephalus, L. idus, Eurasian minnow Phoxinus phoxinus (L., 1758), S. erythrophthalmus, G. gobio, B. barbus, chirruh snowtrout Schizothorax esocinus Heckel, 1838, A. alburnus, schneider Alburnoides bipunctatus (Bloch, 1782), B. bjoerkna, A. brama, B. sapa, and other species (Shultz, Gvozdev, 1970; Dubinina, 1987).

Five tapeworm species of the genus Proteocephalus were found. Proteocephalus cernue (Gmelin, 1790) were found in G. cernua, Proteocephalus esocis (Schneider, 1905) in E. lucius, Proteocephalus percae (Müller, 1780) in P. fluviatilis, Proteocephalus sagittus (Grimm, 1872) in M. fossilis, and Proteocephalus torulosus (Batsch, 1786) were found in S. erythrophthalmus, A. alburnus, and A. brama. These tapeworms are parasites of freshwater fish. There are one or two intermediate hosts and definitive hosts in the life cycle of the genus Proteocephalus. Procercoids develop in crustaceans, the first intermediate hosts: Cyclops, Eucyclops, Macrocyclops and others. The development in a piscine host depends on the fish species. If a procercoid occurs in the intestine of a definitive host, it can develop into a plerocercoid and then into an adult tapeworm. If a procercoid occurs in the intestine of a nonspecific host, it develops into a plerocercoid and remains in this stage until its access to the specific definitive host. The life cycle may also include paratenic hosts (Shultz, Gvozdev, 1972; Dubinina, 1987).

Plerocerci of tapeworm Neogryporhynchus cheilancristrotus (Wedl, 1855) was found in fish of five species: S. erythrophthalmus, T. tinca, A. brama, C. carassius, and G. cernua. The definitive hosts of this cestode are herons (Dubinina, 1987). Their life cycle includes two intermediate hosts: cercoscoleci develop in cyclopid copepods Mesocyclops oithonoides (Jarecka, 1970) and plerocerci in the intestines of freshwater fish, particularly cyprinids (Dubinina, 1987). In zope Ballerus ballerus (L., 1758) from the Oder River, $N$. cheilancristrotus metacestodes are found throughout the year, but the dynamics of infection parameters indicates that there are two main periods of new infections: spring and late autumn-early winter (Pietrock, Scholz, 2000). Unlike the majority of cestodes inhabiting the gut lumen of fish and attaching to the gut epithelium, $N$. cheilancristrotus intrudes into deeper layers of the gut wall. Histological findings show that $N$. cheilancristrotus is a pathogenic species causing degeneration and inflammation in the intestinal wall (Molnár, 2005). According the review by Scholz et al. (2004), the geographic distribution of $N$. cheilancristrotus covers Belarus, Bulgaria, the Czech Republic, Germany, Hungary, Italy, Lithuania, Moldova, Poland, Romania, Russia, Slovakia, and Ukraine in Europe and Azerbaijan, Georgia, Iraq, Japan, Kazakhstan, Tajikistan, Turkmenia, and Uzbekistan in Asia. The morphological descriptions of $N$. cheilancristrotus (e.g., length of rostellar hooks) provided by most authors differ from those provided by Dubinina (1987) and some uncertainty in the taxonomy of gryporhynchid metacestodes exists (Pietrock, Scholz, 2000).

Cestodes Valipora campylancristrota (Wedl, 1855) and Valipora sp. were found in gall bladders of E. lucius. The definitive hosts of this cestode are herons (Dubinina, 1987). Their life cycle includes two intermediate hosts: the first intermediate hosts are crustaceans and the second intermediate hosts are fish. The most common host of the cestode are T. tinca, but parasites are found in many cyprinids and predatory fish. According to the review by Scholz et al. (2004), the geographic distribution of $V$. campylocristrota covers: Czech Republic, Germany, Hungary, Italy, Latvia, Lithuania, Moldavia, Poland, Romania, Russia, Slovakia, the Ukraine, former Yugoslavia (Monte Negro) in Europe; Iraq, Japan, Kazakhstan, Mongolia, Tajikistan, Uzbekistan in Asia; Canada and Mexico in North America; and Brazil in South America. In Lithuania, V. campylocristrota were registered under the name of Valipora unilateralis (Rauckis, 1988). In pond fisheries V. campylocristrota cause decrease in 
the fish mass and growth and if it occurs in high intensities, it may cause fish death (Dubinina, 1987; Ermolenko, 2000).

Nematodes Raphidascaris acus (Bloch, 1779) were found in E. lucius. R. acus is a widely distributed parasite in various predatory fish in the Holarctic; in Europe, the most frequent definitive hosts are E. lucius and S. trutta morpha fario but it also occurs in other fish species (Moravec, 1994). Various invertebrate (oligochaetes, crustaceans and aquatic insects) are preintermediate paratenic hosts of the second stage larvae (Moravec, 1994). There is an opinion that these invertebrates are to be considered as the first intermediate hosts (Vismanis et al., 1987). Various species of fish and cyclostomes, and more rarely, amphibians are intermediate hosts; the third stage larvae in the liver of an intermediate host are infective to a definitive host (Moravec, 1994). Some invertebrate (e.g., Gammarus fussarum) may also serve as true intermediate hosts (Moravec, 1996), but most invertebrates play a role as paratenic hosts only (Moravec, 2004). The maturation cycle of $R$. acus is seasonal, but it may be different in different ecological conditions (Moravec, 2004).

Desmidocercella sp. larvae were found in fish of three species: R. rutilus, S. erythrophthalmus and $P$. fluviatilis. Larvae parasitise in ocular vitreous of Cyprinidae and Percidae in the lakes of Lithuania and Belarus (Vismanis et al., 1987; Rauckis, 1988). Adults of the Desmidocercella genus parasitise in air sacks of herons, bitterns and cormorants (Vismanis et al., 1987).

Nematodes Camalanus lacustris (Zoega, 1776) were found in the intestines of fish of three species: E. lucius, S. erythrophthalmus and $P$. fluviatilis. The definitive hosts of this nematode are fish of the Percidae and Esocidae families and also many other fish (Vismanis et al., 1987; Rauckis 1988). Females of the nematode are viviparous, larvae with faeces of fish get into the water and are swallowed by intermediate hosts - copepods, in the body cavity of which C. lacustris develop; larvae moult two times and become infective for definitive hosts (Vismanis et al., 1987).
Nematodes Skrjabillanus scardinii Molnár, 1966 (syn. Agrachanus scardinii) were found in kidneys of S. erythrophthalmus. Adults of this nematode parasitise on the serosa of swimbladder, kidneys, and intestine and on the mesentery of S. erythrophthalmus (Vismanis et al., 1987; Anderson, 2000). The first-stage larvae are carried in blood to the skin, where small accumulations from five to 50 individuals could be found. Intermediate hosts - the ectoparasitic brachiurans, Argulus coregoni and A. foliaceus - ingest larvae while feeding. Larvae move to haemocoel of crustaceans and later resettle to the legs, where two moults take place. The third-stage larvae leave the mouth parts of brachiurans while the latter are feeding. Larvae invade the fish, migrate to the serous membranes and mature (Tikhomirova 1971, 1975, 1980 cited according Anderson 2000; Vismanis et al., 1987).

Acanthocephalan Neoechinorhynchus rutili (Müller, 1780) was found in S. erythrophthalmus. The species is a wide spread parasite of many species of fish, mostly cyprinids in Eurasia and North America (Bauer, Skryabina, 1987) also found in Africa e.g. Nigeria (Olurin, Somorin, 2006). Intermediate hosts are alderflies Sialis sp. (possibly paratenic host) and ostracods, Candona spp. and Cypria spp. (Bauer, Skryabina, 1987).

Acantacephalus lucii (Müller, 1776) was found in fish of five species: E. lucius, A. brama, L. lota, G. cernua and P. fluviatilis. The species parasitises a wide range of carnivorous and benthofagous fish. The intermediate host is Asellus aquaticus (Bauer, Skryabina, 1987).

\section{CONCLUSIONS}

Sixty-three species or higher taxa of helminths were identified in fish of 23 species. Fifty-six taxa of Plathyhelminthes, five Nematoda, and two Acanthocephales were found. Monogenea $G y$ rodactylus truttae were registered in Lithuania for the first time. For the identified helminths, fish are the only hosts (monogeneans), definitive hosts (part of trematodes, some cestodes, 
some nematodes and all acanthocephalans), intermediate and definitive hosts (some trematodes, some cestodes and some nematodes), and intermediate hosts (part of trematodes, some cestodes and some nematodes); where fish are intermediate hosts, piscivorous birds are the definitive hosts.

The highest number of helminth taxa was found in predatory fish: E. lucius and P. fluviatilis, 20 and 18, respectively. A relatively large number of helminth taxa were also found in cyprinids: R. rutilus and S. erythrophthalmus, 15 and 17 , respectively. In fish of other species, from two to 11 helminth taxa were found.

Metacercariae of flukes Diplostomum sp., Posthodiplostomum cuticola and Tylodelphys clavata were found in the biggest number of host species; 16, 11, and 12, respectively. All other helminths were found in hosts of 1-7 species.

The GLMM shows that six cyprinid species - R. rutilus, S. erythrophthalmus, L. leuciscus, S. cephalus, B. bjoerkna and A. bra$m a$ - have a greater probability of infection with Diplostomum sp. metacercariae. In addition, the GLMM shows that the random effect (the type of Lithuanian inner water) is also statistically significant. There is a statistically significant difference between the fish distribution in Lithuanian inner water body types. The differences in the prevalence of infection in different water body types are significant for some fish species, e.g., for S. erythrophthalmus and B. bjoerkna. Higher prevalence of infection in S. erythrophthalmus with Diplostomum sp. metacercariae was established in rivers compared to lakes. The prevalence in B. bjoerkna was higher in lakes.

Significant differences of prevalence of infection with $P$. cuticola metacercariae in different water body types were established for E. lucius, G. cernua and P. fluviatilis. In these hosts, $P$. cuticola metacercariae were found only in rivers.

Significant differences of prevalence of infection with $T$. clavata metacercariae in various water body types were established for R. rutilus, S. erythrophthalmus, and P. fluviatilis. In fish of these species, higher prevalence values were es- tablished in lakes or the Curonian Lagoon. This can be explained by the fact that definitive hosts of the parasite (grebes) live in standing waters.

Received 15 November 2021 Accepted 7 December 2021

\section{References}

1. Anderson RC. Nematodes parasites of vertebrates, their development and transmission. 2nd ed. Walingford: CABI Publishing: 2000.

2. Bacevičius E. Investigation of helminths of smelt (Osmerus eperlanus m. eperlanus) from south-eastern Baltic Sea and Curonian Lagoon. Fishery and Aquaculture in Lithuania. 2002; 4: 217-32.

3. Bacevičius E. Review of research into metazoan parasites of lamprey and fish from the Curonian Lagoon and Baltic Sea, Lithuanian coastal zone. Jūra ir aplinka. 2003; 2: $57-66$.

4. Bacevičius E. The new data on ecology of alien fish species and fish metazoan parasites in the Curonian Lagoon and Lithuanian Coastal Zone. Baltic - the sea of aliens, Gdynia, Poland 25-27 August 2004. Book of Abstracts, p. 17-18.

5. Bacevičius E. The first record of the fourhorn sculpin (Triglopsis quadricornis Linnaeus, 1758): Actinopterigii: Scorpaeniformes: Cottidae) in the south-eastern part of the Baltic Sea (Lithuanian shallow waters). Acta Zoologica Lituanica. 2009; 19: 324-9.

6. Bacevičius E, Karalius S. A common sole (Solea solea Linnaeus, 1758): Actinopterygii: Pleuronectiformes: Soleidae) caught in the coastal zone of Lithuania. Acta Zoologica Lituanica. 2008; 18: 174-9.

7. Bagdonas K, Nika N, Bristow G, Jankauskienè R, Salyte A, Kontautas A. First record of Dicentrarchus labrax (Linnaeus, 1758) from the southeastern Baltic Sea (Lithuania) J Appl Ichthyol. 2011;27: 1390-1. 
8. Barger MA, Esch GW. Plagioporus sinitsini (Digenea: Opecoelidae): a one-host life cycle. J Parasitol. 2000; 86: 150-3.

9. Barskaya YY, Ieshko EP, Lebedeva DI. Parasites of salmonidae fish of Fennoscandia, Practical guide. Petrozavodsk, Russia, Karelian Sc.C. RASc; 2008.

10. Bauer ON, Skryabina ES. Phylum Acanthocephalans - Acanthocephales. In: Bauer ON, editor. Key to the parasites of freshwater fish fauna of the USSR. Vol. 3. Parasitic Metazoans (part two). Leningrad: Nauka Publishing Leningrad branch; 1987. p. 311-39.

11. Bauer ON (ed.). Key to the parasites of freshwater fish fauna of the USSR. Vol. 2. Parasitic Metazoans (part one). Leningrad: Nauka Publishing Leningrad branch; 1985. $425 \mathrm{p}$.

12. Bauer ON (ed.). Key to the parasites of freshwater fish fauna of the USSR. Vol. 3. Parasitic Metazoans (part two). Leningrad: Nauka Publishing Leningrad branch; 1987. $583 \mathrm{p}$.

13. Bush AO, Lafferty KD, Lotz JM, Shostak AW. Parasitology meets ecology on its own terms: Margolis et al. revisited. J. Parasitol. 1997; 83: 575-83.

14. Bykhovskaya-Pavlovskaya IE. Fish parasitological examination. Leningrad: Nauka Publishing Leningrad branch; 1969. 109 pp.

15. Bykhovskaya-Pavlovskaya IE, Kulakova AP. Class Trematoda Rudolphi, 1808. In: Bauer ON. (ed.) Key to the parasites of freshwater fish fauna of the USSR. Vol. 3. Parasitic Metazoans (part two). Leningrad: Nauka Publishing Leningrad branch; 1987. p. 77-198.

16. Chappell LH, Hardie LJ, Secombes CJ. Diplostomiasis: the disease and host-parasite interactions. In: Pike AW., Lewis JW (eds.) Parasitic diseases of fish. Otley: Samara Publishing Ltd.; 1994. pp. 59-86.

17. Dubinina MN. Class tapeworms - Cestoda Rudolphi. 1808. In: Bauer ON (ed.) Key to the parasites of freshwater fish fauna of the USSR. Vol. 3. Parasitic Metazoans (part two). Leningrad: Nauka Publishing Leningrad branch; 1987. p. 5-76.
18. Ergens RR. Order Gyrodactylea Bychowsky, 1937. In: Bauer ON (ed.) Key to the parasites of freshwater fish fauna of the USSR. Vol. 2. Parasitic Metazoans (part one). Leningrad: Nauka Publishing Leningrad branch; 1985. p. 269-347.

19. Ermolenko AV. Some aspects of the valiporosis manifestation in reared fish. Parazitologiya. 2000; 34: 147-9.

20. Galazzo DE, Dayanandan S, Marcogliese DJ, McLaughlin JD. Molecular systematics of some North American species of Diplostomum (Digenea) based on rDNA sequence data and comparisons with European congeners. Can. J. Zool. 2002; 80: 2207-17.

21. Haarder S, Jørgensen K, Kania PW, Skovgaard A, Buchmann K. Occurrence of Diplostomum pseudospathaceum Niewiadomska, 1984 and D. mergi Dubois, 1932 (Digenea: Diplostomidae) in Danish freshwater snails: ecological and molecular data. Folia Parasit. 2013; 60: 177-80.

22. Ieshko EP. Population biology of fish helminths. Leningrad: Nauka Publishing Leningrad branch; $1988.118 \mathrm{p}$.

23. Jarecka L. On the life cycles of Paradilepis scolecina (Rud., 1819) Hsü, 1935 and Neogryporhynchus cheilancristotus (Wedl, 1855) Baer \& Bona, 1958-1960 (Cestoda: Dilepididae). Bulletin de l'Académie Polonaise des Sciences, Classe II, Série des Sciences Biologiques. 1970; 18: 159-63.

24. Locke SA, McLaughlin JD, Dayanandan S, Marcogliese DJ. Diversity and specificity in Diplostomum spp. metacercariae in freshwater fish revealed by cytochrome $c$ oxidase I and internal transcribed spacer sequences. Int $\mathrm{J}$ Parasitol. 2010a; 40: 333-43.

25. Locke SA, McLaughlin JD, Marcogliese DJ. DNA barcodes show cryptic diversity and a potential physiological basis for host specificity among Diplostomoidea (Platyhelminthes: Digenea) parasitizing freshwater fish in the St. Lawrence River, Canada. Mol Ecol. 2010b; 19: 2813-27.

26. Molnár K. Histopathological changes caused by the metacestodes of Neogryporhynchus 
cheilancristrotus (Wedl, 1855) in the gut of the Gibel carp, Carassius gibelio. Acta Vet Hung. 2005; 53: 45-52.

27. Moravec F. Parasitic nematodes of freshwater fish of Europe. Prague and Dordrecht, Boston, London: Academia and Kluwer Academic Publishers; 1994. 473 p.

28. Moravec F. The amphipod Gammarus fossarum as a natural true intermediate host of the nematode Raphidascaris acus [Abstract]. J Parasitol. 1996; 82: 668-9.

29. Moravec F. Observations on the transmission and the seasonality of infection of the nematode Raphidascaris acus in Salmo trutta fario in a small trout stream in Noeth Bohemia, Czech Republic. Helmintologia. 2004; 41: 91-7.

30. Našincová V, Scholz T. The life cycle of Asymphylodora tincae (Modeer 1790) (Trematoda: Monorchiidae): A unique development in monorchiid trematodes. Parasitol Res. 1994; 80: 192-7.

31. Niewiadomska K. Family Diplostomatidae Poirier, 1886. In: Gibson D I, Jones A, Bray RA (eds.) Keys to the Trematoda. Vol. 1. London: CABI Publishing and The Natural History Museum; 2001a. p. 167-96.

32. Niewiadomska K. Family Strigeidae Railliet, 1919. In: Gibson DI, Jones A, Bray RA (eds.) Keys to the Trematoda. Vol. 1. London: CABI Publishing and The Natural History Museum; 2001b. p. 231-41.

33. Niewiadomska K, Laskowski Z. Systematic relationships among six species of Diplostomum Nordmann, 1832 (Digenea) based on morphological and molecular data. Acta Parasitol. 2002; 47: 20-8.

34. Noga EJ. Fish disease: diagnosis and treatment. 2nd ed. Ames, Iowa: Wiley-Blackwell Publishing; $2010.536 \mathrm{p}$.

35. Olurin KB, Somorin CA. Intestinal Helminths of the Fish of Owa Stream, South-west Nigeria. RJFH. 2006; 1: 6-9.

36. Oškinis V. Population biology of fish helminths and the effect of thermal pollution of the Ignalina Nuclear Power Plant on the populations of fish helminths in the Lake Drūkšiai (Lithuania). Kaunas: Vaidoto Oškinio Publishing; $1993.78 \mathrm{p}$.

37. Petkevičiūtė R, Stunžènas V, Stanevičiūtè G, Sokolov SG. Comparison of the developmental stages of some European allocreadiid trematode species and a clarification of their life-cycles based on ITS2 and 28S sequences. Syst. Parasitol. 2010; 76: 169-78.

38. Pietrock M, Scholz T. Morphometrics and seasonal occurrence of metacestodes of Neogryporhynchus cheilancristrotus (Cyclophyllidea: Dilepididae) in the blue bream (Abramis ballerus) from the Oder River (Germany/Poland). Folia Parasit. 2000; 47: 181-5.

39. Pilecka-Rapacz M, Kesminas V. Investigations of the nematode Anguillicola crassus (Nematoda, Dracunculoidea) in Lake Dringis, Lithuania. Ekologija. 2006; 4: 65-9.

40. Rakauskas V, Bacevičius E, Pūtys Ž, Ložys L, Arbačiauskas K. Expansion, feeding and parasites of the round goby, Neogobius melanostomus (Pallas, 1811), a recent invader in the Curonian Lagoon, Lithuania. Acta Zoologica Lituanica. 2008; 18: 180-90.

41. Rakauskas V, Blaževičius Č. Distribution, prevalence and intensity of roach (Rutilus rutilus (Linnaeus, 1758)) parasites in inland waters of Lithuania in 2005-2008. Acta Zoologica Lituanica. 2009; 19: 99-108.

42. Rakauskas V, Blaževičius Č. An assessment of parasite variation in wild populations of roach, Rutilus rutilus (L.), in Lithuanian rivers. Arch Pol Fish. 2010; 18: 213-23.

43. Rauckis E. Fish parasites of Lithuanian waters. Vilnius: Mokslas Publishing; 1988. 207 p.

44. Roberts LS, Janovy J. Gerald D. Schmidt \& Larry S. Roberts' foundations of parasitology. 8th ed. Boston: McGraw-Hill Publishing; 2008. $701 \mathrm{p}$.

45. Rojtman VA, Lobanov AL. Method of estimation of parasite hemipopulation abundance in host population. In: Sonin MD, editor. Research on morphology, taxonomy and biology 
of bird helminths. proceedings of helminthology laboratory. Moscow: Nauka Publishing; 1985; 33: 102-23.

46. Scholz T, Bray RA, Kuchta R, ̌̌epová R. Larvae of gryporhynchid cestodes (Cyclophyllidea) from fish: a review. Folia Parasit. 2004; 51: 131-52.

47. Shultz RS, Gvozdev EV. Basics of general helminthology. Vol. 1. The morphology, systematics, phylogeny of helminths. Moscow: Nauka Publishing; 1970. 492 p.

48. Shultz RS, Gvozdev EV. Basics of general helminthology. Vol. 2. The biology of helminths. Moscow: Nauka Publishing; 1972. 515 p.

49. Sokolov SG, Tseitlin DG, Afanasyev KI, Malinina TV, Rubtsova GA. A comparative study of trematodes, Bunodera luciopercae luciopercae(Müller, 1776) and B. l. acerinae Rojtman et Sokolov, 1999 (Trematoda: Bunoderidae). Invertebrate Zoology (Zoologiya bespozvanochnykh). 2006; 3: 209-23.

50. Stankus S. Helminths of perch and bream of the Curonian Lagoon. Fishery and Aquaculture in Lithuania. 1996; 2: 197-202.

51. Szidat L. Contribution to the fauna and biology of Curonian harbour. Schriften der Physikalisch-Ökonomischen Gesellschaft zu Köningsberg. 1926; 65: 5-31.

52. Szidat L. Further investigation on the digenean fauna of local freshwater fish. Zeitschrift für Parasitenkunde. 1944; 13: 183-214.

53. Šimková A, Morand S. Co-evolutionary patterns in congeneric monogeneans: a review of Dactylogyrus species and their cyprinid hosts. J Fish Biol. 2008; 73: 2210-27.

54. Virbickas J. Lithuanian fish. Vilnius: Trys Žvaigždutès Publishing; 2000. 192 p.

55. Vismanis KO, Lomakin VV, Rojtman VD, Semenova MK, Trofimenko VYa. Phylum Nemathelminths - Nemathelminthes. In: Bauer ON (ed.) Key to the parasites of freshwater fish fauna of the USSR. Vol. 3. Parasitic Metazoans (part two). Leningrad: Nauka Publishing Leningrad branch; 1987. p. 199-310.
56. Wegener G. Ectoparasites of fish from East-Prussian. Schriften der PhysikalischÖkonomischen Geselschaft zu Köningsberg. 1909; 50: 195-286.

57. Zhokhov AE. Host specificity of flukes of the genus Sphaerostomum (Trematoda: Opecoelidae) within their geographic ranges. Russ J Ecol. 2002; 33: 417-22.

\section{Vytautas Mažeika, Saulius Petkevičius, Egidijus Pumputis, Ričardas Krikštolaitis}

\section{ŽUVŲ HELMINTAI LIETUVOS VIDINIUOSE VANDENYSE}

\section{Santrauka}

Tirti Lietuvos vidaus vandenų 23 žuvų rūšių helmintai. Nustatyti 63 helmintų taksonai: 56 plokščiųjų kirmèlių, 5 nematodų ir 2 akantocefalų. Monogeneja Gyrodactylus truttae Lietuvoje registruota pirmą kartą. Diplostomum sp., Posthodiplostomum cuticola ir Tylodelphys clavata metacerkarijų aptikta daugiausia šeimininkų rūšių - atitinkamai 16, 11 ir 12. Bendrasis tiesinis mišrus modelis (GLMM) rodo, kad 6 karpinių žuvų rūšys - Rutilus rutilus, Scardinius erythrophthalmus, Leuciscus leuciscus, Squalius cephalus, Blicca bjoerkna ir Abramis brama - turi didesnę tikimybę užsikrèsti Diplostomum sp. metacerkarijomis. GLMM taip pat patvirtina statistiškai reikšmingą atsitiktinị efektą (Lietuvos vidaus vandenų tipas). İvairiuose vandens telkinių tipuose nustatyti žuvų užsikrètimo Diplostomum sp., P. cuticola ir T. clavata metacerkarijomis ekstensyvumo skirtumai.

Raktažodžiai: helmintai, žuvis, vidiniai vandenys, Lietuva 